\title{
Tectonic Control of the Reykjanes Geothermal Field in the Oblique Rift of SW Iceland: From Regional to Reservoir Scales*
}

\author{
Maryam Khodayar"\#, Sveinbjörn Björnsson2 ${ }^{2}$ Egill Árni Guðnason1, Steinpór Níelsson1, \\ Guðni Axelsson" ${ }^{1}$, Catherine Hickson ${ }^{3}$ \\ ${ }^{1}$ Iceland GeoSurvey (ÍSOR), Reykjavík, Iceland \\ ${ }^{2}$ National Energy Authority of Iceland, Reykjavík, Iceland \\ ${ }^{3}$ Tuya Terra Geo Corporation, Burnaby, Canada \\ Email: "mak@isor.is, "Profnet10@gmail.com, svb@orkugardur.is, egill.arni.gudnason@isor.is, steinthor.nielsson@isor.is, \\ Gudni.Axelsson@isor.is, cathie@ttgeo.ca
}

How to cite this paper: Khodayar, M., Björnsson, S., Guðnason, E.Á., Níelsson, S., Axelsson, G. and Hickson, C. (2018) Tectonic Control of the Reykjanes Geothermal Field in the Oblique Rift of SW Iceland: From Regional to Reservoir Scales. Open Journal of Geology, 8, 333-382. https://doi.org/10.4236/ojg.2018.83021

Received: February 11, 2018

Accepted: March 27, 2018

Published: March 30, 2018

Copyright (๑) 2018 by authors and Scientific Research Publishing Inc. This work is licensed under the Creative Commons Attribution-NonCommercial International License (CC BY-NC 4.0). http://creativecommons.org/licenses/by-nc/4.0/ (c) (i) \&) Open Access

\begin{abstract}
This paper presents a multidisciplinary structural analysis of the Reykjanes Peninsula where Holocene deformation of a young oblique rift controls the geothermal processes in presence of a transform segment. The new structural map from aerial images and outcrops is correlated with selected surface and subsurface data and shows a complex pattern: NNE extensional rift structures, N-S dextral and ENE sinistral oblique-slip Riedel shears of the transform zone, and WNW and NW dextral oblique-slip faults. Shear fractures are more common, and along with the NNE fractures, they compartmentalise the crustal blocks at any scale. The fractures are within two ENE Riedel shear zones, indicating a minimum $7.5 \mathrm{~km}$ wide transform zone. The greatly deformed Southern Riedel Shear Zone is bounded to the north and the south by the 1972 and the 2013 earthquake swarms. This shear zone contains the geothermal field in a highly fractured block to the west of a major NW structure. Some of the deformations are: a) clockwise rotation of rift structures by the 1972 earthquake zone, inducing local compression; b) magma injection into extensional and oblique-slip shear fractures; c) reactivation of rift structures by transform zone earthquakes; d) tectonic control of reservoir boundaries by
\end{abstract}

"Correction for the downloads: An error occurred regarding Figure 5 of the paper: "Tectonic Control of the Reykjanes Geothermal Field in the Oblique Rift of SW Iceland: From Regional to Reservoir Scales" by "Khodayar et al.", which was first published on the OJG site on March 31, 2018. Figure 4 appeared twice, once as Figure 4, and once as Figure 5. The journal has corrected this error and the available PDF online now shows both Figures correctly for new downloads. Readers who download the first PDF file of this paper between March 31 and April 1, 2018 are invited to download the corrected file. 
WNW and ENE shear fractures, and the distribution of surface alteration, fumaroles, $\mathrm{CO}_{2}$ flux, reservoir fluid flow and the overall shape of pressure drawdown by N-S, ENE, WNW/NW and NNE fractures. Results demonstrate the role of seismo-tectonic boundaries beyond which fault types and density change, with implications for permeability.

\section{Keywords}

Oblique Rift, Transform Zone, Reykjanes Peninsula, Tectonic Control of Geothermal Activity, Fractured Reservoir

\section{Introduction}

The Reykjanes high-temperature geothermal field is located to the southern tip of Reykjanes Peninsula (RP) in Iceland, on the traces of the Reykjanes-Langjökull Rift Zone (RLRZ) and the westward continuation of the South Iceland Seismic Zone (SISZ) transform zone (Figures 1 (a)-(c)). The geothermal field is relatively small $\left(1-2 \mathrm{~km}^{2}\right)$ with a reservoir temperature up to $320^{\circ} \mathrm{C}$ at $3 \mathrm{~km}$ depth [1]. About 36 wells drilled shallower than $3 \mathrm{~km}$ supply steam to a name-plate 100 $\mathrm{MW}_{\mathrm{e}}$ electric power plant operating since 2006. The Iceland Deep Drilling Project-2 (IDDP-2) deepened a well from $2.5 \mathrm{~km}$ to $4.7 \mathrm{~km}$ in 2016 and tapped into $427^{\circ} \mathrm{C}$ supercritical fluid at $4.6 \mathrm{~km}$ depth [2]. Deep drilling results are subject to a separate analysis.

Geothermal reservoirs are fractured in many structural contexts [3]-[9] and tectonic activity controls many processes from magma emplacement (heat source) to the loci of geothermal activity and the permeability [10] [11] [12] [13]. Tectonic is, therefore, key for exploration and production. As on RP tectono-magmatic fractures form within an oblique rift [14] [15] [16], a quick look at the characteristics of such rifting is necessary.

Oblique rifting occurs in both continent and oceanic rifts and ridges [7] [17]-[25] when the direction of relative plate motion is not parallel to the principal strain directions [26] [27] and the plates spread obliquely compared to the rift/ridge trend [28]. Such rifts are considered to initiate above inherited non-aligned crustal weak zones [29]-[36] where strain is localised [37] [38] and magmatism is present at depth [39] [40].

Outcrop mapping, as well as analogue and numerical modelling show that oblique rifting is accommodated by both normal and strike-slip faults, and characterised by typical en échelon sigmoid segments that are surface expression of deeper structures [21] [33] [41]-[48]. The angle $(\alpha)$ between rift/ridge trend and the direction of relative plate spreading determines whether a rift is moderately $\left(\alpha=15^{\circ}\right.$ to $\left.45^{\circ}\right)$ [48] or highly $\left(\alpha=45^{\circ}-75^{\circ}\right)$ oblique [44]. Rift obliquity also determines the orientation, timing of appearance of each fracture type within the rift/ridge axes, and the disappearance of rift boundary normal faults. Consensus is that all normal, strike- and oblique-slip faults have formed by $\alpha=30^{\circ}$ [28] [44] [48]. 


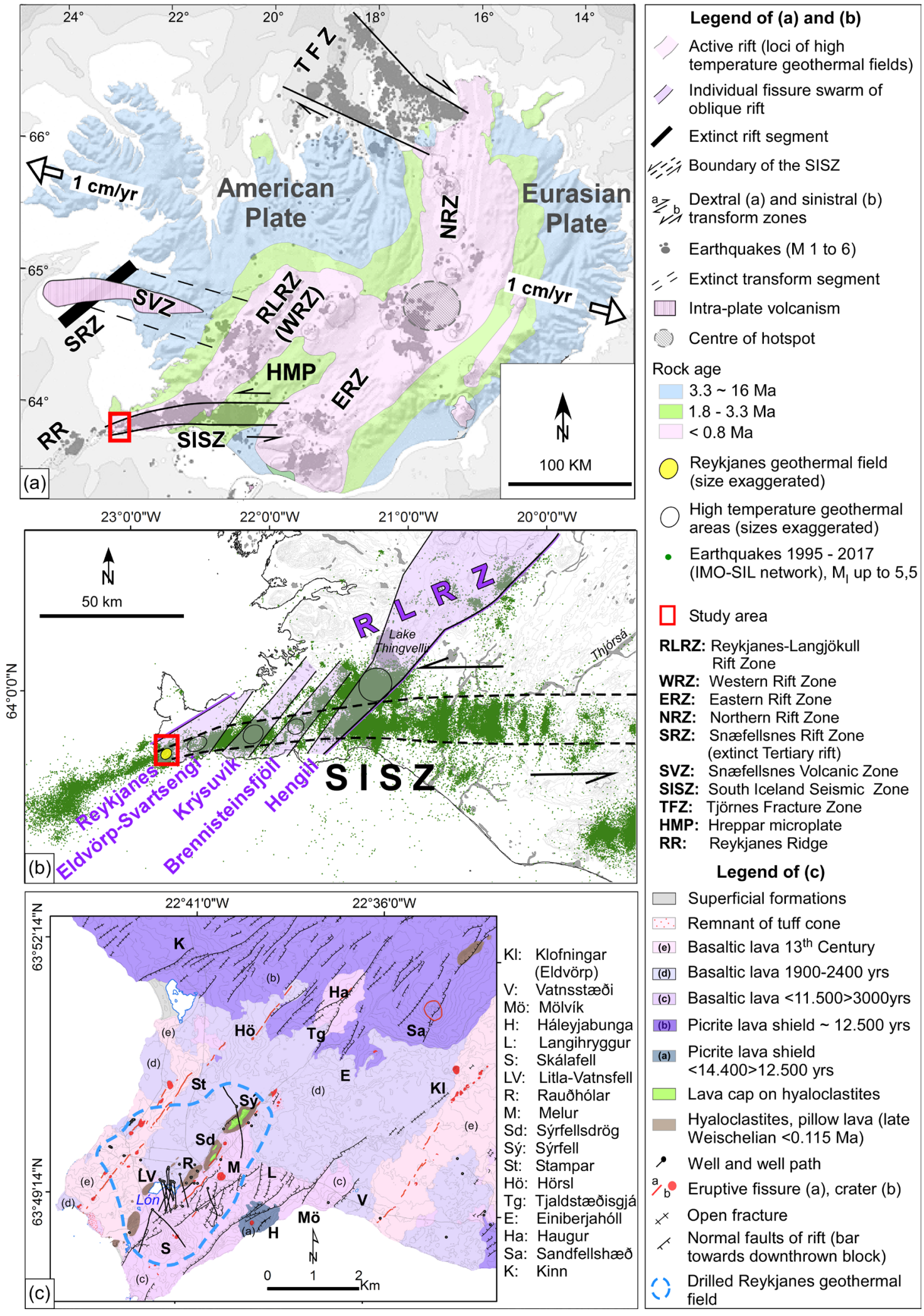

Figure 1. (a) Main geological elements of Iceland. Rock ages, active rift and intra-plate volcanism, outline of active rift and transform segments (after [56]); Earthquakes (after [81]); Suggested abandoned Tertiary transform zone (after [86]). (b) Close up of tectonic elements of Southwest Iceland. Fissure swarms and geothermal fields (after [105]); Earthquakes from Icelandic Meteorological Institute (IMO). (c) Extent of Reykjanes geothermal field based on drilled wells. 
Over their few million years of evolution from the stages of continental break-up to oceanic spreading [49] [50], oblique rifts can develop with or without transform segments [25] [51] [52] [53] [54], or with initial transfer zones that evolve into transform zones [24]. Other complexities are migration of deformation, expressed as gradual curvature of rift/ridge axis and their internal en échelon segments reflecting changes in rift obliquity [6] [40] [55] [48], stress field re-orientation/permutation and polyphase tectonics [57] [58] [59].

In addition to RP [14] [15] [16], oblique rifting takes place on the Iceland shelf along Reykjanes Ridge (RR) [60] [61] and in the Tjörnes Fracture Zone (Grímsey Oblique Rift-GOR) [62]. All these areas are considered to be at a young stage of rifting where fracturing is organised in en échelon segments. However, the tectonic pattern of these areas is more complex due to the activity of the transform zones.

Both the RR and RP [63] are highly oblique $\left(\alpha=30^{\circ}-40^{\circ}\right)$ compared to the direction of plate motion at $\mathrm{N} 103^{\circ} \mathrm{E}$ [64]. On RP, the NE normal faults as well as the N-S and ENE conjugate strike-slip faults have been modelled in clay experiments [16], the geothermal reservoir parametres are well known, and present-day crustal deformation and earthquakes monitored. RP has undergone deformation since the Holocene, and very likely been under long-term influence of both the rift and the transform mechanisms. However, geothermal activity at RP has been primarily interpreted in terms of simple rifting [1]. Some topics such as a comprehensive structural map of both plate boundary types and their combined role in the geothermal processes are not fully discussed.

In order to assess the combined role of rifting and transform faulting in the geothermal processes in Reykjanes, a new multidisciplinary structural analysis was carried out for HS Orka and Alterra Group between 2014 and 2016 [65]. The results were used to site additional wells in the reservoir area [66] [67], and formed part of the European project DEEPEGS (Deployment of Deep Enhanced Geothermal Systems). The purpose of this paper is to present selected results of the original multidisciplinary structural analysis by disseminating the following data and results:

- New structural maps of the geothermal field and its surrounding as well as surface geothermal manifestations, prepared from aerial images and outcrops.

- Analysis and interpretation of the fracture sets and their style of deformation.

- Correlation between results of the new structural investigations and selected geological and geophysical data to show the combined role of rift and transform zones in the control of the Reykjanes geothermal field.

The new findings are relevant for geothermal field management in general, and contribute to further understanding of oblique rifting in the presence of a transform segment, with implications for volcanism, geothermal fluid flow and permeability. 


\section{Geological Setting}

Iceland is above a hotspot [68] [69] and a Tertiary member of the North Atlantic Igneous Province since the opening of the North Atlantic at 62 - $58 \mathrm{Ma}$ [70] [71]. The oldest series onshore are 16 - $15 \mathrm{Ma}$ [72] [73], possibly even $24 \mathrm{Ma}$ [74], and the island displays series of active and extinct rift and transform segments (Figure 1(a)), as well as intra-plate earthquakes [75] and volcanism [76] [77]. The active rift segments are the RLRZ, as well as the Eastern and Northern Rift Zones (ERZ, NRZ). The transform segments, identified by large and frequent earthquakes [78] [79] [80] [81], are the Tjörnes Fracture Zone (TFZ) and the SISZ (Figure 1(a)). Successive rift jumps [82] [83] [84] led to a series of parallel extinct rift segments from central Iceland to the northwest, and to possible Tertiary transform segments in central and west Iceland [83] [85] [86].

Rift segments are characterised by fissure swarms of parallel normal faults, eruptive fissures and dykes, calderas, acidic rocks [87] [88], and high temperature geothermal fields [89]. The Krafla events of 1976-1984 [90] and the 2014 eruption of Holuhraun in Bárðarbunga [91] showed that rift episodes consist of dyke injection as well as vertical and horizontal ground displacements. The transform zone earthquakes occur due to rupture of strike- and oblique-slip faults [92] [93] [94] [95] [96]. Particularly in the SISZ, earthquakes are periodic, reaching $M_{L} 7$ [94]. The sinistral motion of this E-W transform segment is accommodated by the Riedel shears, striking dominantly N-S and ENE [94], and secondarily WNW, NW, and E-W [96].

The North American and Eurasian Plates separate at about $18.8 \mathrm{~mm} / \mathrm{yr}$ in the direction $\mathrm{N} 103^{\circ} \mathrm{E}$ [64] along the active rift and transform segments. In south Iceland, it is estimated that about 10\% [94], 15\% [97] or even 35\% [98] of the total spreading rate takes place along the RLRZ. Oblique rifting takes over from south of RLRZ to RP [14] [15] [16], and to RR [60] [99] with typical V-shape geometry [100] and pseudo faults [101] on the Iceland shelf. Both onshore [63] [102] and offshore [24] [61], the en échelon segmentation is the main structural feature within the rift/ridge axis.

The configuration of plate boundaries changes onshore from the RLRZ westward where rifting becomes oblique on RP. The rift segment splits into narrower parallel fissure swarms, namely, Hengill, Brennisteinsfjöll, Krýsuvík, and Reykjanes-Eldvörp-Svartsengi, and the transform zone changes direction from E-W to ENE before joining RR offshore (Figure 1(b)). It is suggested that oblique rifting and magmatic phases alternate on RP [103], and that presently the peninsula undergoes oblique rifting where the plate boundary is transtensional with both left-lateral motion and extension [104]. Mapping of fractures on RP shows the distribution of the rift normal faults and eruptive fissures [105] [106], and the main conjugate N-S and ENE sets of strike-slip faults [63]. Similar to the SISZ, on RP earthquakes are periodic, every 30 years on average, with $M_{L}$ up to 6 [94]. The best recorded events on RP are the 1972 earthquakes, outlining a zone of $\mathrm{N} 55^{\circ} \mathrm{E}$ to $\mathrm{N} 77^{\circ} \mathrm{E}$, up to $2 \mathrm{~km}$ in width and $12 \mathrm{~km}$ in length [107].

$\mathrm{RP}$ is at a young stage of rifting as indicated by primitive magma (olivine 
tholeite and picrites) and absence of central volcanoes and shallow magma chambers despite the presence of acidic rocks and high temperature geothermal fields [108] [109]. The geothermal fields are located at the intersection of each rift fissure swarm and the transform zone [105] (Figure 1(b)).

The study area is covered by postglacial Holocene lavas and two isolated hyaloclastite ridges (Sýrfell/Rauðhólar and Litla-Vatnsfell) aged $<0.115 \mathrm{Ma}$ (Figure 1(c)) [110] [111]. The postglacial lavas have minimal erosion and consist of the basaltic shields and picrites (Háleyjabunga and Sandfellshæð) aged $14.500-12.500$ yrs, and the 11.500 to 2000 yrs basaltic lavas from Vatnsstæði to Stampahraun. The youngest lavas of RP are Stampar and Eldvörp, which were emitted during 13th century from fissures forming crater rows [106]. These young series are found to a depth of $400 \mathrm{~m}$ in wells above other lavas, hyaloclastites and geothermally altered sediments with marine shells and tuffs (400 - $1200 \mathrm{~m})$, and a sequence of pillow lava, fine- and coarse-grained intrusions (1200 to $3000 \mathrm{~m}$ ) [111] [112] [113]. The heat source could be a dyke or even sills, doming up under the production zone as indicated by the deep intrusions in wells [1] [114]. Permeability is fracture controlled. However, only few of the rift and transform zone fracture sets were thoroughly mapped and interpreted above the reservoir until recently. Results of a new mapping and the interpretation of the tectonic control of the geothermal activity [65] [114] are presented in this paper.

Note that the last eruptive fissures in the eastern part of the study area are within the Eldvörp geothermal field. As Klofningar lavas surround these crater rows, we use Klofningar as the name when referring to these eruptive fissures in our study.

\section{Method and Data}

Previous works on Reykjanes geothermal field have shed light on the relative shape and depth of the reservoir, its temperature, pressure, flow rates, stratigraphic formations, and provided a simplified tectonic model focused on rifting, e.g. [1] [111]. Of all the extensional and shear fracture sets present within the rift and transform zones on RP, three (NNE, N-S, ENE) have been mapped [16] [105], and those are to the north and east of the study area. The actual reservoir area represents a knowledge gap as only a few of the prominent faults and eruptive fissures belonging to three fracture sets have been identified [103] [105]. As both plate boundaries play a role in the control of geothermal processes, it is crucial to have a comprehensive map of the fracture pattern and use it as the basis for a multidisciplinary structural analysis of other surface and sub-surface data. This paper presents results of such an analysis based on the following methods and data:

a) A new structural map of Reykjanes and its interpretation

- This base map was prepared by extracting the structures from four types of aerial images (pairs of aerial photographs analysed in stereo, Spot 5 images, orthomaps, and hillshade). Additionally, outcrops of major faults, mineral veins, joints, dykes, alteration, fumaroles, surface temperature measurements, and source faults of earthquakes were also analysed to determine the 
style of deformation.

- The structural pattern was subjected to an initial kinematic and dynamic interpretation.

b) A multidisciplinary analysis

The following surface and sub-surface data gathered independently were correlated and interpreted in light of the new structural map:

- The $\mathrm{CO}_{2}$ surface flux monitoring [115].

- The earthquakes of 1972 [107] and 2013-2015 [116] [117].

- The overall pressure drawdown at $1600 \mathrm{~m}$ in the reservoir (courtesy of Ómar Sigurðsson, HS Orka, 2014).

- Recovery of tracer [118] injected into two wells (RN-20 and RN-33) to identify the carrier and barrier structures to the flow.

- InSAR measurements of the period 2009-2013 [119].

\section{Multidisciplinary Tectonic Investigations}

A step-by-step structural analysis is carried out in this chapter to identify the tectonic structures and their roles in the geothermal processes. At first, the tectonic pattern obtained from aerial images and outcrop mappings is presented, followed by the interpretation of the fracture sets, their style of deformation and their possible kinematics. Then, the surface geothermal manifestations mapped in this study, along with geological and geophysical data mentioned above are interpreted in light of the new structural data. The subsequent interpretation of some of the regional and local structures aims at explaining their critical role in the location of the geothermal field and many of its processes at surface and depth.

\subsection{Observation of the Structural Architecture}

The interpreted structural pattern of Reykjanes is shown on a combined Spot 5 and hillshade base image (Figure 2). This pattern results from observations of the aerial images available for the study as well as the analysis of selected outcrops to detect the nature and relevant features of the structures (Figure 2). As the structures cut mostly the post-glacial series younger than 14.500 yrs (Figure 1(c)), they reflect a young stage of tectonic deformation.

\subsubsection{Aerial Images}

To identify the overall structural architecture, the morphostructures from a hillshade map with $5 \mathrm{~m}$ contour-interval (database of Iceland GeoSurvey-ÍSOR) and a Digital Elevation Model (DEM) map with a $2.5 \mathrm{~m}$ contour interval (Loftmyndir) were analysed. These image types reflect mostly the overall regional and major structures. However, as they do not provide sufficient resolution for finer structures, the analysis was completed using monochrome aerial photographs, as well as orthomaps and Spot 5 images in several channels for enhanced shadow/lights. Pairs of aerial photographs provided stereographic observations and a means to see the structures in relief and assess the dip direction of the fractures. Individual fractures, however, may appear with a slightly different trace 


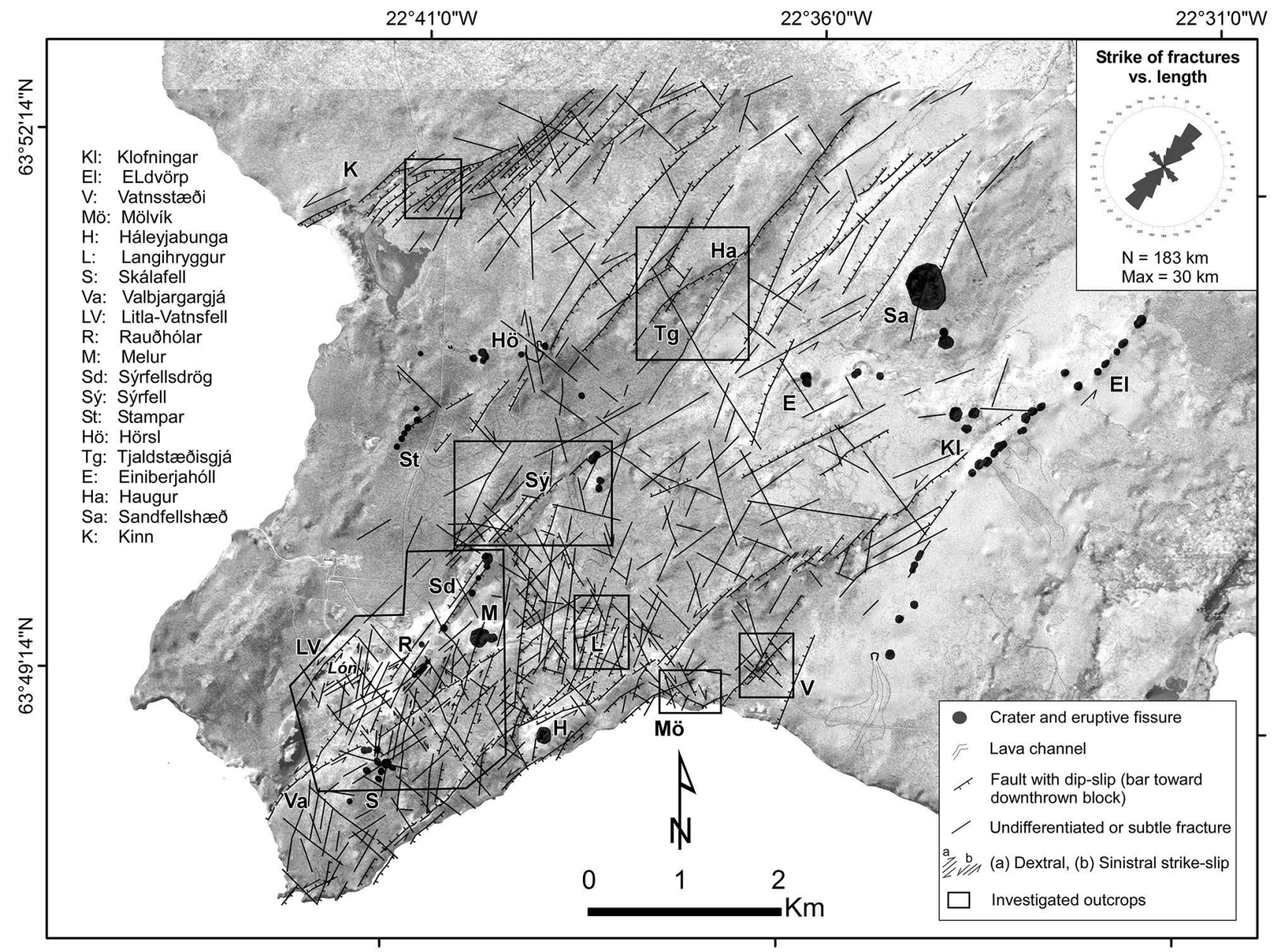

Figure 2. Interpreted structural pattern of rift and transform zone in Reykjanes from aerial images and outcrops, reported on a combined support of hillshade and Spot 5 images.

and geometry on each image type, depending on the direction of the light. Thus drawn fractures are "best fit" of their traces on all images.

The number of sets and distribution of the fractures obtained from aerial images and selected outcrops are shown on the enlarged (Figure 2), and detailed views of the study area including mapped surface geothermal manifestations (Figure 3). The rose diagram on Figure 2 shows that the NE and NW fractures are the most frequent in the entire study area, but local statistical analysis may show other dominant frequencies, depending on the location of the studied area within the overall tectonic pattern.

Individual fractures are segmented along their trace, and segments can be as short as a few metre(s) or reach up to $2 \mathrm{~km}$ in length. Joints or very young fractures that have not yet coalesced or fully broken the surface have more subtle traces (hair line), particularly in lavas $<2400 \mathrm{yrs}$, and may be mistaken as lava structures or go undetected. The traces of older structures with accumulated slip are stronger both on images and in outcrops.

Regardless of their age or length, shear fractures present en échelon arrangements, which were used to determine their strike-slip motions as discussed 

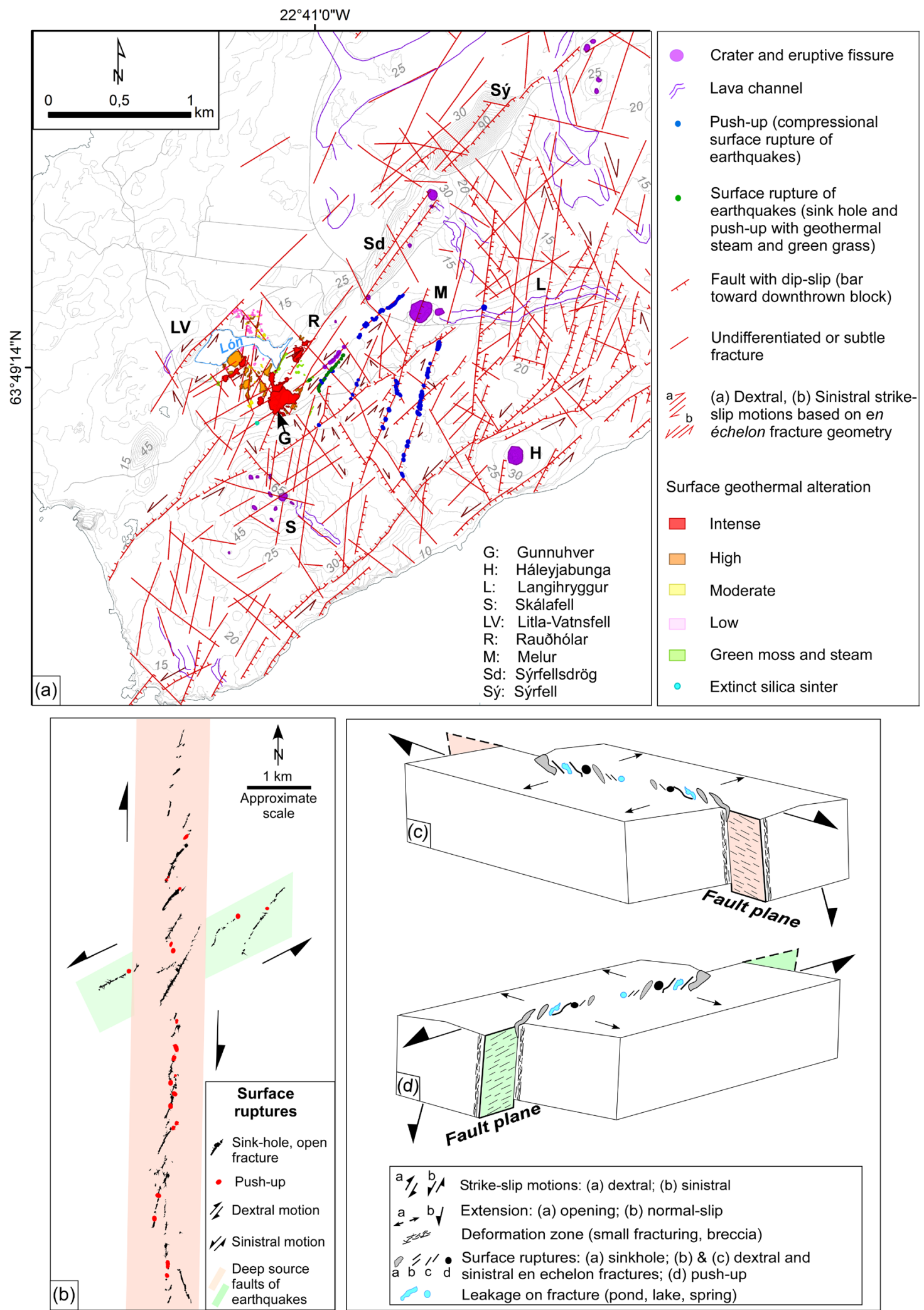

Figure 3. Closer look at the mapped volcanic and tectonic structures at and surrounding Reykjanes geothermal field. (a) Main mapped fault types, surface ruptures of earthquakes, volcanic craters and surface alteration. (b) Left- and right-stepping en échelon arrangements of surface ruptures in view map, indicative of dextral and sinistral motions. (c) and (d) Block diagrams showing the surface ruptures of earthquakes as expression of deeper faults (after [120]). 
below. This criterion shows that the tectonic fabric is made of purely extensional fractures as well as strike- and oblique-slip faults.

\subsubsection{Fracture Sets from Air and Outcrops}

The mapped volcano-tectonic structures are faults (Figures 4(a)-(c)); major joints; rare dykes due to the level of erosion (Figure 4(d), Figure 4(e)); eruptive fissures and craters (Figure 5(b)); surface ruptures of earthquakes (Figure 3(b), Figures 5(a)-(c), Figure 6(a) and Figure 6(b)); and surface geothermal manifestations (Figures 6(a)-(g)). Micro-structures such as mineral veins (Figure 4(f) and Figure 4(g)) and secondary fractures (Figure 5(f) and Figure 5(g)) were also analysed, but striae were not found on any of fracture planes studied.

Six fracture sets emerge from the overall structural analysis: N-S $\left(0^{\circ}-\mathrm{N} 27^{\circ} \mathrm{E}\right)$, $\mathrm{NNE}\left(\mathrm{N} 28^{\circ}-\mathrm{N} 40^{\circ} \mathrm{E}\right), \mathrm{ENE}\left(\mathrm{N} 41^{\circ}-\mathrm{N} 75^{\circ} \mathrm{E}\right), \mathrm{E}-\mathrm{W}$ (on average N90 $\left.{ }^{\circ} \mathrm{E}\right), \mathrm{WNW}$ $\left(\mathrm{N} 115^{\circ}-\mathrm{N} 130^{\circ} \mathrm{E}\right)$, and NW/NNW $\left(\mathrm{N} 140^{\circ}-\mathrm{N} 155^{\circ} \mathrm{E}\right.$ and $\left.\mathrm{N} 165^{\circ} \mathrm{E}\right)$. In the geothermal field and its surroundings, the ENE, N-S and NW sets are the most common. The E-W fractures are the least common in the entire study area and their traces are very subtle, without convincing evidence as to their shear motion.

Dip-slip is associated with all sets (Figures $4(\mathrm{a})-(\mathrm{c})$ ), ranging from $<0.5 \mathrm{~m}$ to $\geq 20 \mathrm{~m}$. The highest slips are along the ENE, N-S and NE faults. Fracture apertures are generally $<0.5 \mathrm{~m}$ (Figure 6(a) and Figure 6(b)), rarely reaching $1 \mathrm{~m}$ in width in the study area.

The NNE/NE fractures parallel to the Reykjanes rift fissure swarm are purely extensional. The en échelon fracture geometries, visible along younger and older fractures, are typically left-stepping along the N-S, WNW and NW dextral faults, and right-stepping along ENE sinistral fractures (Figure 3(b) and Figure 3(c)). The N-S dextral and ENE sinistral strike-slips are the main conjugate source faults of earthquakes and are identical to those found within the pure transform zone of the SISZ farther to the east [94] [120]. The magnitude of offset along the shear fractures could not be identified due to the lack of marker horizons. However, data from the 2008 earthquakes within the SISZ itself indicate that the offset along an individual N-S dextral source fault is about $2 \mathrm{~m}$ [95]. In the $15 \mathrm{Ma}$ old lavas of west Iceland, sets of dykes are shifted up to $20 \mathrm{~m}$ by strike-slip faults [121] [122] indicating cumulative displacement likely due to fault reactivation during their lifetime.

The source faults of earthquakes in Reykjanes consist of sink-holes, open fractures and push-ups. The mapping of these surface ruptures in the SISZ [94] [120] shows that sink-holes and open fractures are more frequent than the push-up along a single fault. But in this part of Reykjanes, push-ups are by far the most dominant structures both along the N-S and the ENE faults (Figure 3(a), Figures 5(a)-(c), Figure 6(a) and Figure 6(b)), and their significance is further analysed with the earthquakes in Chapter 4.3.2 below.

The only dyke segments cropping out in the study area are at Rauðhólar (Figure 4(d) and Figure 4(e)). Even if they are in soft hyaloclastite host rock, which 

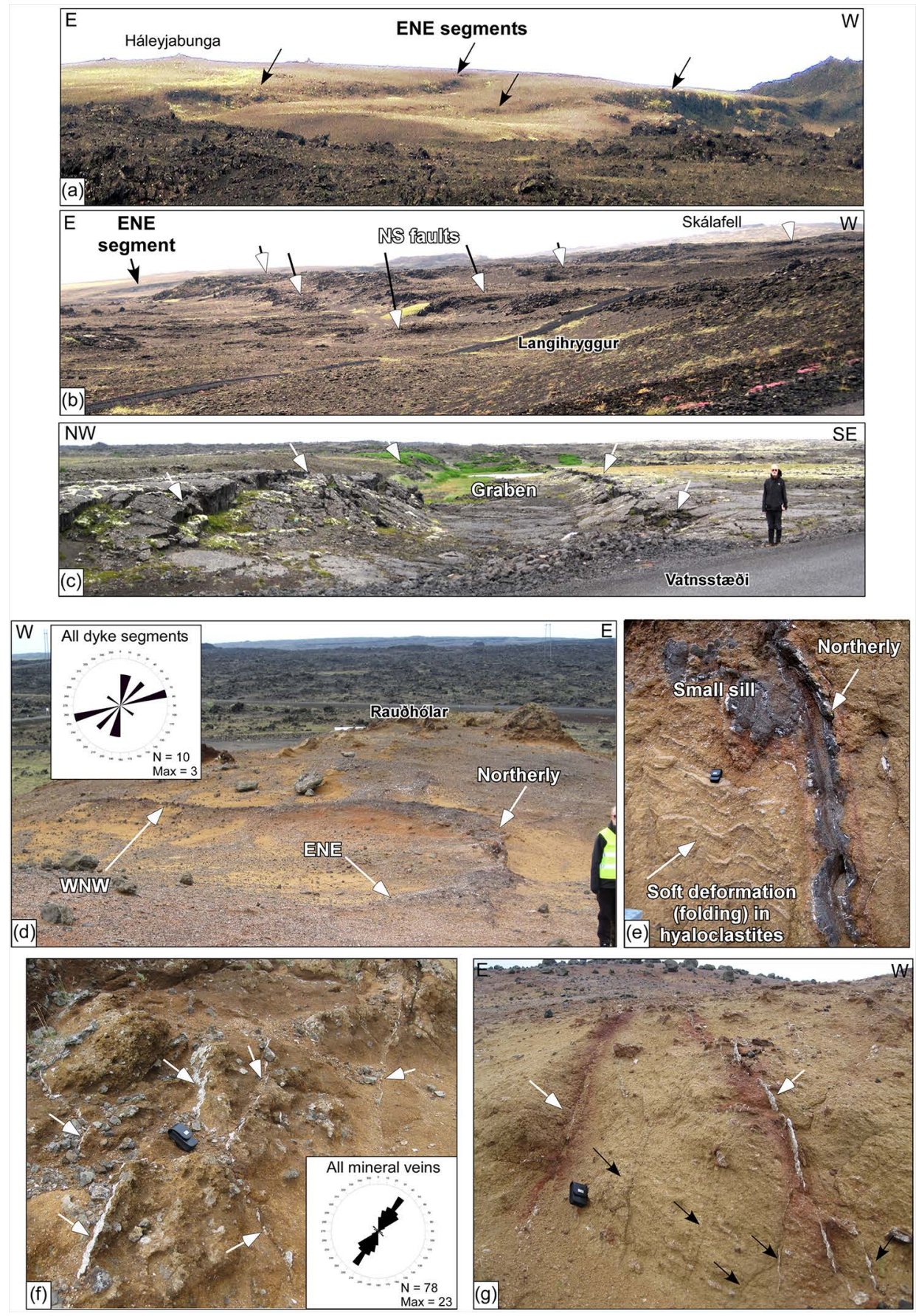

Figure 4. Volcanic and tectonic structures in outcrops. (a) Major ENE oblique-slip fault to the north of Háleyjabunga with right-stepping en échelon segmentation typical of sinistral motion, and vertical offset up to $20 \mathrm{~m}$. (b) Parallel N-S faults of Langihryggur with vertical offsets up to $5 \mathrm{~m}$ and possible dextral motions. (c) A narrow graben with clear boundary faults and metre-scale vertical slip at Vatnsstæði. The structure strikes $\mathrm{N} 48^{\circ} \mathrm{E}$ and falls within the strike-range of ENE sinistral strike- and oblique-slip conjugate faults of the transform zone. (d) Dyke segments in the hyaloclastites of Rauðhólar above the geothermal reservoir, and the rose diagram of all segments mapped there. Dyke curvature and bifurcation result from intersection of three segments striking WNW, N-S and ENE. (e) A short N-S dyke segment displaying pillow-like sills shooting off the main segment. Soft deformation (folding) indicates that magma injected into unconsolidated hyaloclastites. (f) Mineral veins with inconclusive cross-cutting orders in the hyaloclastites of Rauðhólar, and the rose diagram of all veins measured there. (g) Thicker NE-striking mineral veins (up to $4 \mathrm{~cm}$ ) and red contact metamorphism (white arrows), and thinner veins without contact metamorphism in the hyaloclastites (black arrows). 

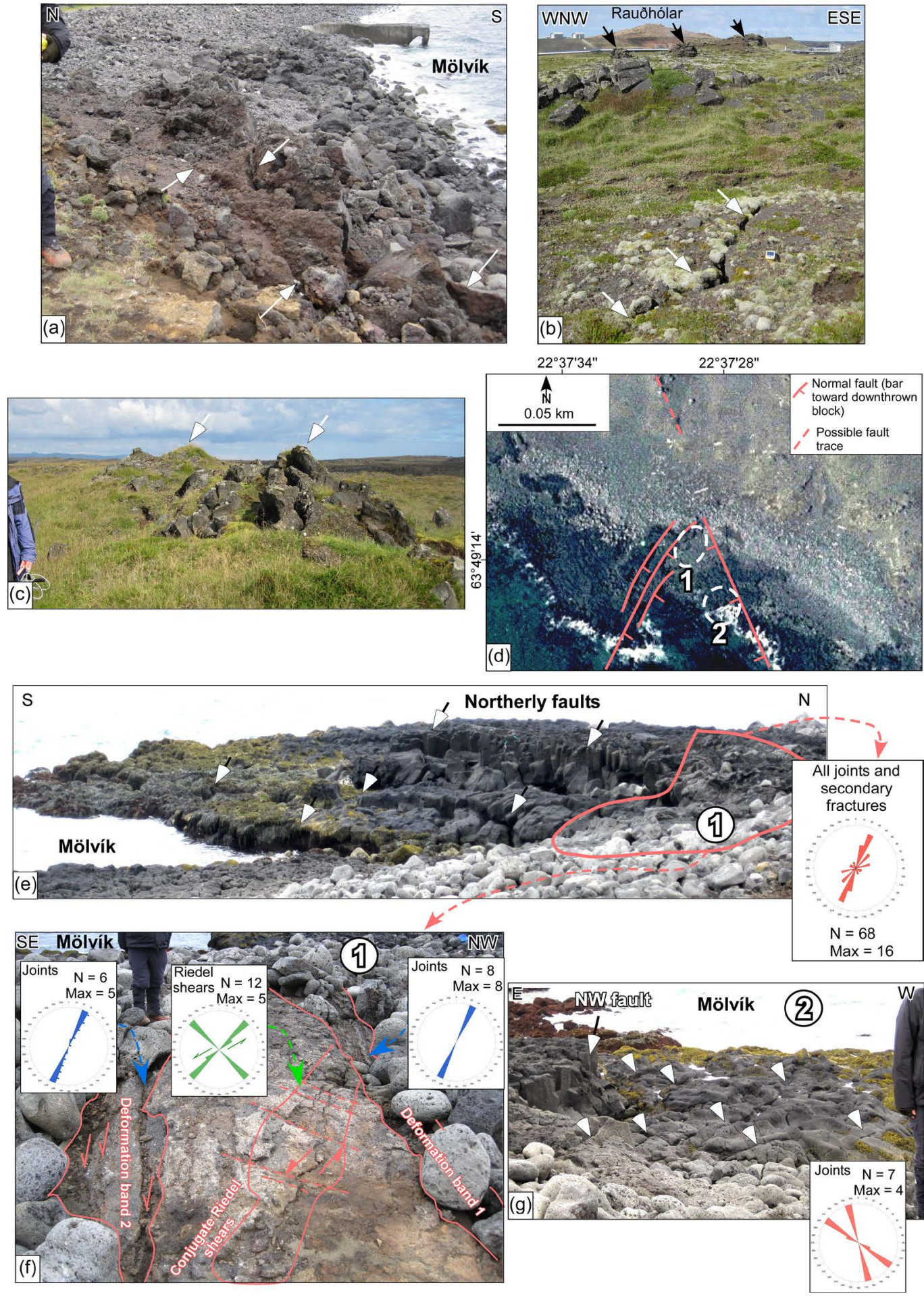

Figure 5. Tectonic structures in outcrops. (a) Freshly broken ENE fractures at Mölvík on the trace of 2013 earthquake swarm. (b) Open fracture to the east of Rauðhólar belonging to surface ruptures of earthquakes. (c) Shape and dimension of a typical compressional push-up along a source fault of earthquakes. (d) The N-S and NW faults of Mölvík seen on OrthoMap, along with the site of secondary fracture measurements. (e) View on the N-S fault scarps with meter-scale vertical displacements to the east, and the associated secondary fractures in site (1). (f) Close look at the deformation bands, breccia, and Riedel shears along the N-S faults in site (1). The deformation bands 1 and 2 strike $\mathrm{N} 30^{\circ}-\mathrm{N} 40^{\circ} \mathrm{E}$ and contain small normal faults up to $3 \mathrm{~cm}$ dip-slip to the east. The ENE Riedel shears reach $7 \mathrm{~cm}$ opening (at the arrows), and are cut by WNW joints. (g) View southeast on the NW fault with a meter-scale dip-slip to the west. Note the strikes of the measured joints in the hanging wall of the fault. 

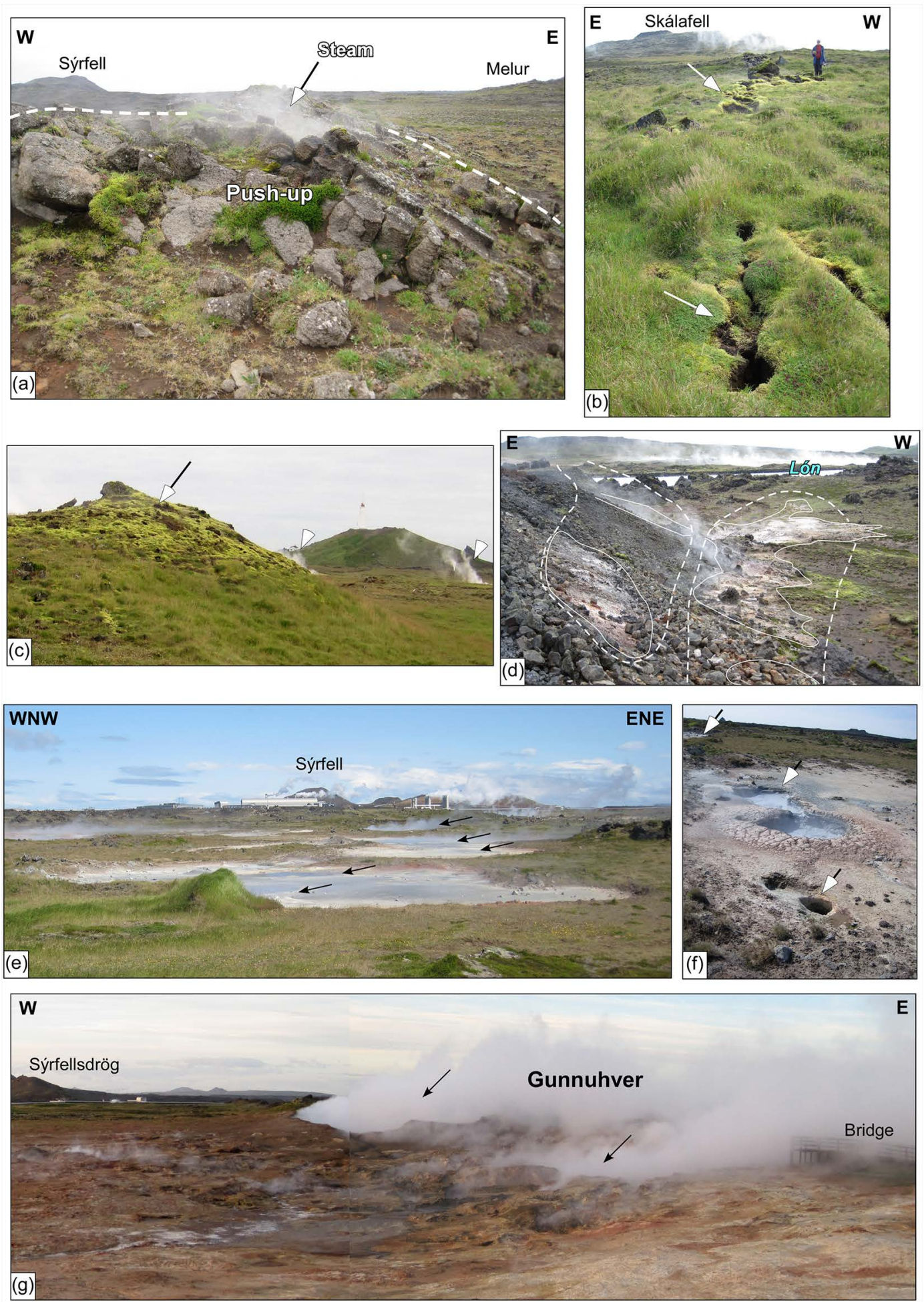

Figure 6. Example of mapped surface geothermal manifestations in outcrops. (a) One of the ENE push-ups to the northeast of Rauðhólar from which geothermal steam escapes. (b) Sink-holes in a right-stepping en échelon arrangement from which geothermal steam escapes altering the grass. (c) Warm ground with low alteration, steam and greener grass. (d) The most prominent high alteration spots to the north of Lón, organised in left-stepping en échelon arrays, indicative of a dextral strike-slip host fracture. (e) The alteration zones and the biggest mud pools, and (f) some fumaroles, all aligned ENE in a right-stepping en échelon arrangement typical of sinistral host fracture. (g) The biggest mud pools of Gunnuhver in the southeast of the mapped geothermal area are aligned NNE. 
could influence their strikes, the mapped dyke segments strike dominantly ENE, and then N-S and NNE, and finally WNW (Figure 4(d)), reflecting the strikes of the faults (Figure 2).

\subsubsection{Secondary Fractures}

Due to minimal level of erosion of the young series, deeper parts of fault zones do not crop out for structural analysis. However, mineral veins and secondary fractures were measured in rare sites.

Two sets of mineral veins cut the hyaloclastites of Rauðhólar above the geothermal reservoir (Figure $4(\mathrm{f})$ and Figure $4(\mathrm{~g})$ ) in the same outcrop as the mapped dykes (Figure $4(\mathrm{~d})$ ). One set consists of shallow dipping $\left(0^{\circ}-45^{\circ}\right)$ veins parallel to the stratification of the hyaloclastites (Figure 4(e)). As some panels of hyaloclastites and veins are tilted by collapse, the shallow-dipping veins are rootless and do not represent the initial state of fracturing. A second set of veins dipping $45^{\circ}$ to $90^{\circ}$ is also present (Figure $4(\mathrm{f})$ and Figure $4(\mathrm{~g})$ ). Their aperture is from $1 \mathrm{~mm}$ to $3 \mathrm{~cm}$, and their length from 1.5 to $3 \mathrm{~m}$. About 78 such veins were measured (Figure 4(f)) in an area of $300 \mathrm{~m} \times 50 \mathrm{~m}$. The total vein population strikes dominantly $\mathrm{N} 30^{\circ}-\mathrm{N} 40^{\circ} \mathrm{E}$ and parallel to the rift fissure swarm, although locally the veins strike $\mathrm{N} 10^{\circ}-\mathrm{N} 30^{\circ} \mathrm{E}, \mathrm{N} 50^{\circ}-\mathrm{N} 60^{\circ} \mathrm{E}$ and even $\mathrm{N} 110^{\circ}-$ $\mathrm{N} 140^{\circ} \mathrm{E}$ similar to the shear fractures. A few vein cross-cuttings occur, but their order is not coherent enough to conclude a chronology of emplacement. A red contact aureole appears along a handful of veins (Figure 4(g)). Although these veins were not sampled, magma injection was excluded as the reason for the aureoles because these veins are at a significant distance of the mapped dykes at Rauðhólar. Localised alteration along the veins from fluid flow is assumed to cause the aureoles.

Another rare site to the west of Mölvík displays joints and secondary fractures in association with two series of N-S and NW-trending faults (Figures 5(d)-(g)). Three parallel N-S faults by the shoreline strike $\mathrm{N} 22^{\circ} \mathrm{E}$ and bend gently to $\mathrm{N} 28^{\circ} \mathrm{E}$ in their northern parts. They displace the basaltic lavas by 1 to $2.5 \mathrm{~m}$ (Figure 5(e)). About 68 joints measured along these faults (Figure 5(d) and Figure $5(\mathrm{e}))$ strike dominantly $\mathrm{N} 20^{\circ}-\mathrm{N} 30^{\circ} \mathrm{E}$, then $\mathrm{N} 10^{\circ}-20^{\circ} \mathrm{E}$, and to a lesser extent $\mathrm{N} 40^{\circ}-50^{\circ} \mathrm{E}$ and $\mathrm{N} 70^{\circ}-\mathrm{N} 80^{\circ} \mathrm{E}$. Only a few joints strike $\mathrm{N} 100^{\circ}-\mathrm{N} 110^{\circ} \mathrm{E}$ and $\mathrm{N} 150^{\circ}-\mathrm{N} 170^{\circ} \mathrm{E}$. Some of the joints display geometries typical of shear motions (Figure 5(f)). For example, a metre-scale block of lava is bounded by two deformation bands striking $\mathrm{N} 20^{\circ}-\mathrm{N} 30^{\circ} \mathrm{E}$ parallel to the main faults. Each band is at least a metre thick and consists of unbroken lavas alternating with parallel brecciated zones where small dip-slip faults with up to $7 \mathrm{~cm}$ vertical displacement are present (Figure 5(f)). The central block of lava between the two deformation bands is cut by series of joints trending at $50^{\circ}$ oblique to the deformation bands (Figure 5(f)). These joints strike $\mathrm{N} 40^{\circ}-\mathrm{N} 60^{\circ} \mathrm{E}$ and show a sinistral horizontal offset of $5 \mathrm{~cm}$. They are cut by other joints striking $\mathrm{N} 130^{\circ}-\mathrm{N} 140^{\circ} \mathrm{E}$ (Figure 5(f)). The overall structural settings here reflect Riedel shears where the $\mathrm{N}$-S deformation bands act as dextral strike-slip (R') and the ENE set as sinistral 
strike-slip (R), much like the conjugate sets of surface ruptures in the SISZ.

Finally, at a few metres from this outcrop, a short fault segment strikes $\mathrm{N} 163^{\circ} \mathrm{E}$ and dips near vertical, displacing the lava by $1 \mathrm{~m}$ to the west (Figure 5(d) and Figure 5(g)). No breccia is associated with the fault and several regularly-spaced joints, striking $\mathrm{N} 160^{\circ}-\mathrm{N} 170^{\circ} \mathrm{E}$ and $\mathrm{N} 110^{\circ}-\mathrm{N} 130^{\circ} \mathrm{E}$ crop out in the hanging wall of this NW fault (Figure $5(\mathrm{~g})$ ). The NW fault is the continuation of a ridge similar to a horst, which has a km length and stretches northwest to Sýrfell (Figure 2 and Figure 3(a)). The edges of this ridge are gentle and covered by sand. The northeast and southwest scarps strike $\mathrm{N} 139^{\circ} \mathrm{E}$ and $\mathrm{N} 144^{\circ} \mathrm{E}$ and stand higher than the surrounding by $>5 \mathrm{~m}$ and $>3 \mathrm{~m}$, respectively. The ridge could be misinterpreted as a lava structure. However, the freshly ruptured NW faults (Figure 5(g)) and joints (Figure 5(d)) by the shoreline are in the continuation of this ridge, suggesting that the structure is a horst and that it has been activated recently. Similar NW structures with left-stepping segmentation typical of dextral strike-slip are relatively common in the entire study area.

These qualitative observations from rare outcrops of secondary fractures show that the rift extensional fractures and the Riedel shears of the transform zone are both active even at the micro-structural level, which is relevant for fluid flow in the geothermal reservoir.

\subsubsection{Geothermal Activity}

Surface geothermal manifestations crop out only above the reservoir (Figure $3(\mathrm{a})$ ). All surface alteration was mapped, along with the fumaroles, steam vents and mud pools within the alteration zones. Only one extinct silica sinter was found. It dates from 1919 and is located in the southern part of the alteration area. Additionally, soil temperatures were measured with a hand-held thermometer to a maximum depth of $1 \mathrm{~m}$. The structural control of all these manifestations was also assessed [65]. It is emphasised that geothermal activity changes rapidly and may increase or disappear with time. The interpretation discussed here is based on the data gathered during the summer of 2014.

Mapped ground temperatures were as high as $91^{\circ}-100^{\circ} \mathrm{C}$ and as low as $11^{\circ}$ $21^{\circ} \mathrm{C}$ (values $<11^{\circ} \mathrm{C}$ measured in the summer are not representative of geothermal heat). Surface alteration was mapped by visual inspection and ranged from very mild (Figures 6(a)-(c)) to intense (Figure 6(d)-(g)). The mildest alteration appears as unaltered rock with occasional steam escaping from lava or surface ruptures (Figure 6(a) and Figure 6(b)), leading to greener moss (Figure 6(c)) due to warm ground $\left(<40^{\circ} \mathrm{C}\right)$ and humidity.

In more intensely altered areas (Figure $6(\mathrm{~d})$ ), ground temperature is $60^{\circ} \mathrm{C}$ to $80^{\circ} \mathrm{C}$, and local white/red/orange clay is widespread along with small fumaroles and steam vents. In areas of intense alteration where ground temperature is $80^{\circ} \mathrm{C}$ to $<100^{\circ} \mathrm{C}$, the rock is entirely altered to clay, and fumaroles are more frequent and large. Mud pools are quiescent to vigorously boiling and vegetation is totally absent (Figures 6(e)-(g)). Fumaroles and mud pools are generally $<1 \mathrm{~m}$ in diametres except a few mud pools that are up $1.5 \mathrm{~m}$ in size (Figure 6(f)). At the 
time of mapping, Gunnuhver was the biggest fumarole and strongly venting water and steam from craters of 2 to $2.5 \mathrm{~m}$ diametre in size (Figure $6(\mathrm{~g})$ ).

Based on the above observations, alteration is moderate to the north of Lón, mimicking the lava lobes, but more intense to the east, southeast, and mid central area to the south of Lón (Figure 3(a)).

\subsection{Interpretation}

The deformation of the entire RP has been described as a single ENE sinistral shear zone matching the trace of the transform zone, with three fractures sets, i.e. the N-S dextral and ENE sinistral source faults of earthquakes and the NNE extensional fractures of the rift [16]. The interpretation of the six fracture sets here reflects the complexity of rift and transform interaction at an oblique rift, with implications for geothermal activity (Figures 7-11).

\subsubsection{Structural Weak Zones of Each Set}

Several structural weak zones are interpreted within each fracture set (Figures 7 (a)-(f)). These zones appear either as areas of high fracture density, or as single fractures that are prominent compared to their surroundings due to their trace, length, geometry, or higher slip. These zones reflect where most of the deformation is concentrated and fault reactivation occurs.

Individual N-S dextral, ENE sinistral, and WNW to NNW dextral weak shear zones lie parallel to each other with a relatively regular spacing (Figure 7(a), Figure $7(\mathrm{c})$, Figure $7(\mathrm{e})$ and Figure $7(\mathrm{f})$ ). The NNE extensional rift structures are, however, fewer and occupy specific locations within the study area. These NNE zones consist of two grabens with 1 to $1.5 \mathrm{~km}$ width at Haugur and Vatnsstæði (Figure 4(c)), then a series of narrow structures from Skálafell to Rauðhólar and Sýrfell (50 m width), and a series of narrow grabens at Kinn $(<100 \mathrm{~m}$ width) that merge with ENE structures there (Figure $7(\mathrm{~b}))$. Of the fracture sets, the $\mathrm{E}-\mathrm{W}$ is the least frequent and has the shortest and narrowest structures. The structural weak zones of the other five sets are the most prominent, and play a role in geothermal activity as thoroughly discussed in the following chapters:

a) The four westernmost N-S weak zones stretching from Skálafell to north of Lón at Rauðhólar, from east of Skálafell to the northwest of Sýrfell, from the coast to Melur, and from Langihryggur to the northeast of Sýrfell (Figure 7(a)). The most prominent N-S faults within these zones are series of parallel dextral oblique-slip faults with $<10 \mathrm{~m}$ vertical slip covering the area from Langihryggur (Figure 4(b)) towards the geothermal reservoir where a number of young surface ruptures and most of the push-ups (Figure 5(c)) are aligned on them (Figure 3(a)).

b) The NNE segments of Sýrfell/Sýrfellsdrög/Rauðhólar (Figure 7(b)) on the trace of which the only dykes were observed (Figure 4(d) and Figure 4(e)) and mineral veins measured (Figure 4(f) and Figure 4(g)).

c) The six southernmost ENE weak zones starting from Sýrfell/Sandfellshæð 

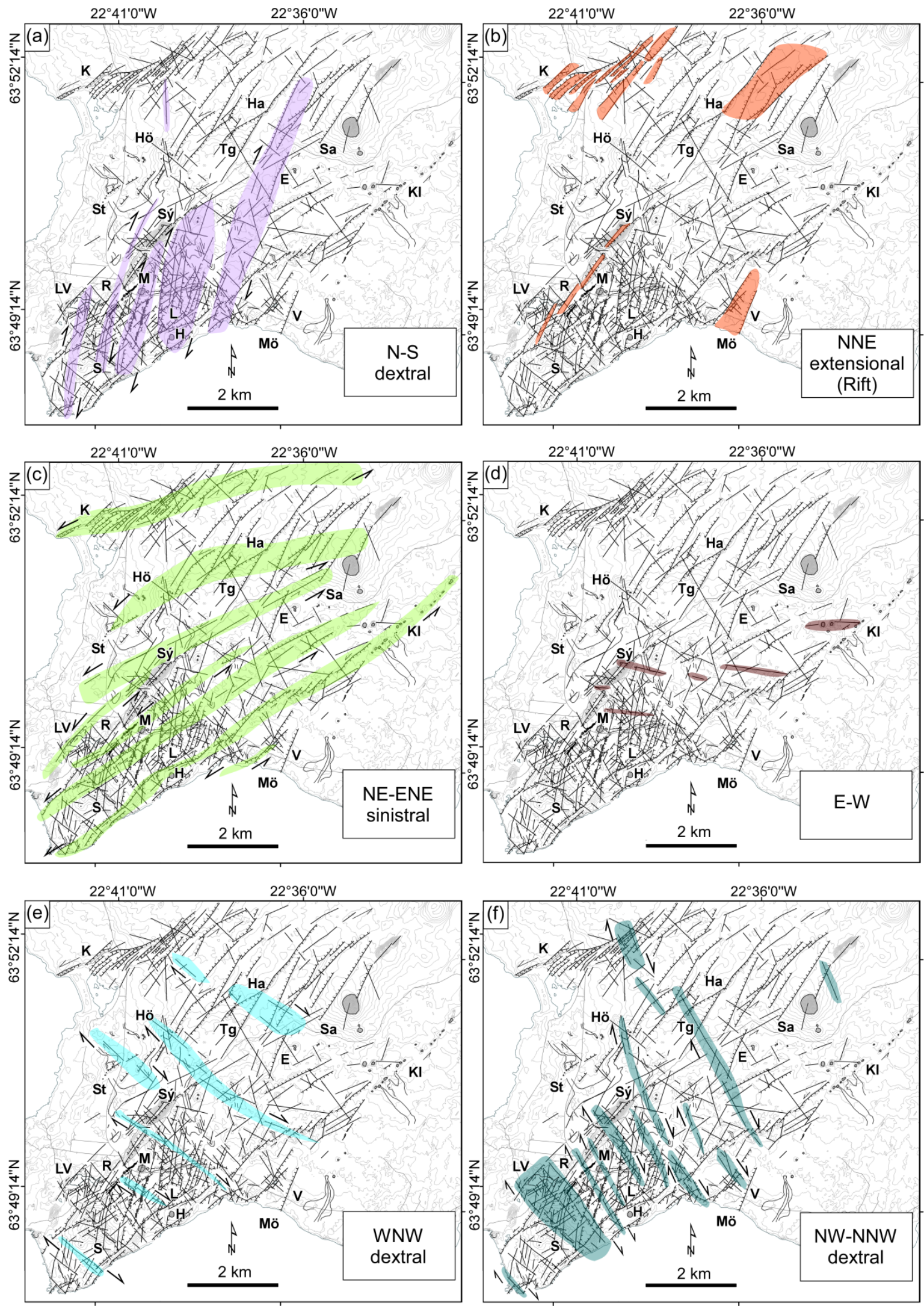

Figure 7. Interpreted structural weak zones. These zones are defined as intensely fractured area or prominent fractures, and are highlighted for each fracture set. (a) N-S. (b) NNE to NE. (c) ENE. (d) E-W. (e) WNW. (f) NW/NNW. 

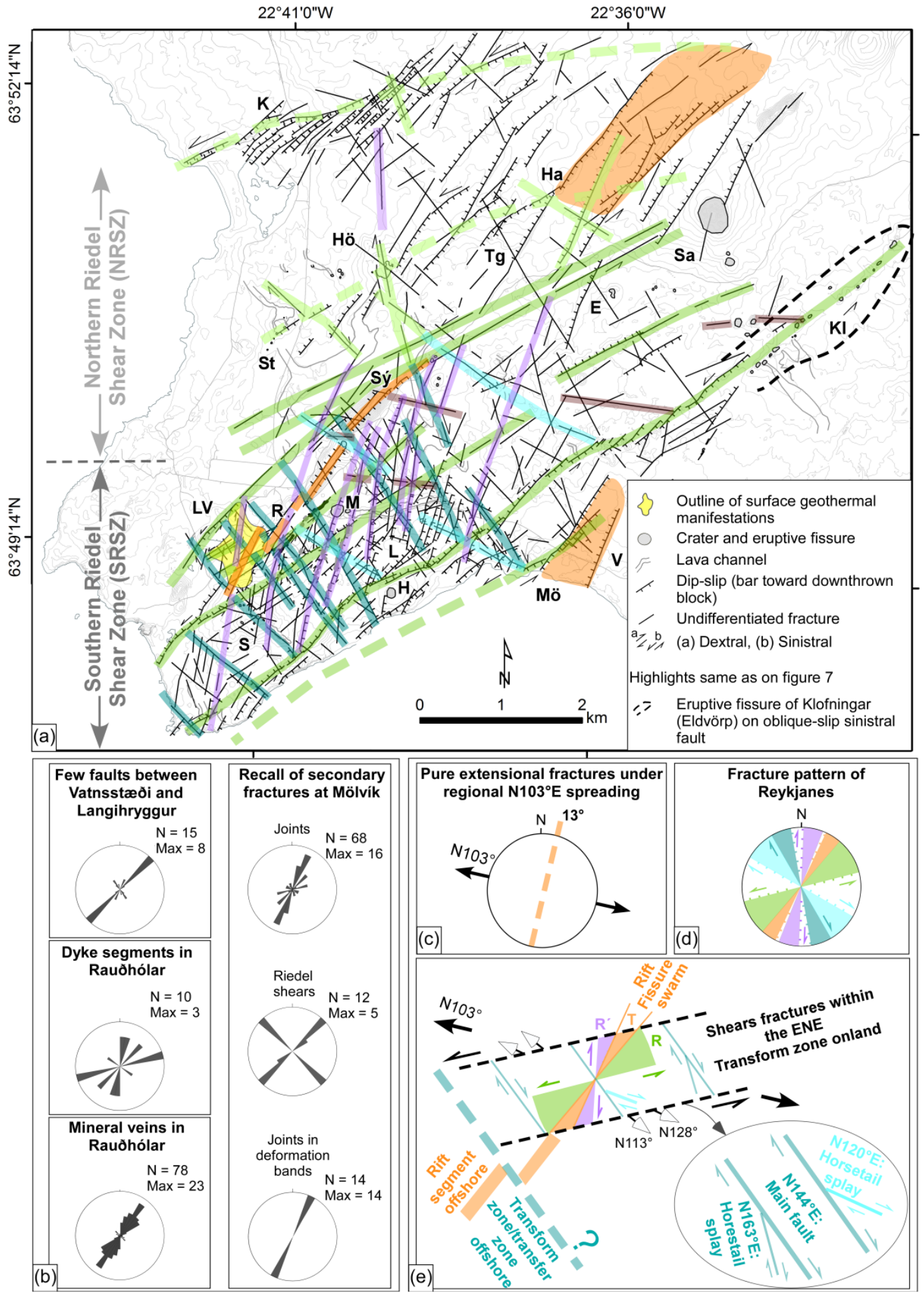

Figure 8. Structural interpretation of the observed fracture pattern in terms of Riedel shear, stress, and kinematics. (a) Individual weak zones are highlighted on the structural map, reflecting a combined pattern of shear and extensional fractures, distributed within a Northern and a Southern Riedel Shear Zone. (b) Recall of the strike of the fractures measured in outcrops. (c) The strike of a pure extensional fracture similar to a rift fissure swarm compatible with a regional spreading at N103 ${ }^{\circ} \mathrm{E}$. (d) The observed strikes and motions of the fractures in Reykjanes. (e) Suggestion of fluctuations in the direction of local extension, and kinematic explanation of the observed fracture pattern including the WNW and NW fractures. The two latter sets act likely as horsetail splays rather than reflecting a second transform zone orthogonal to the active ENE transform zone known onshore. 

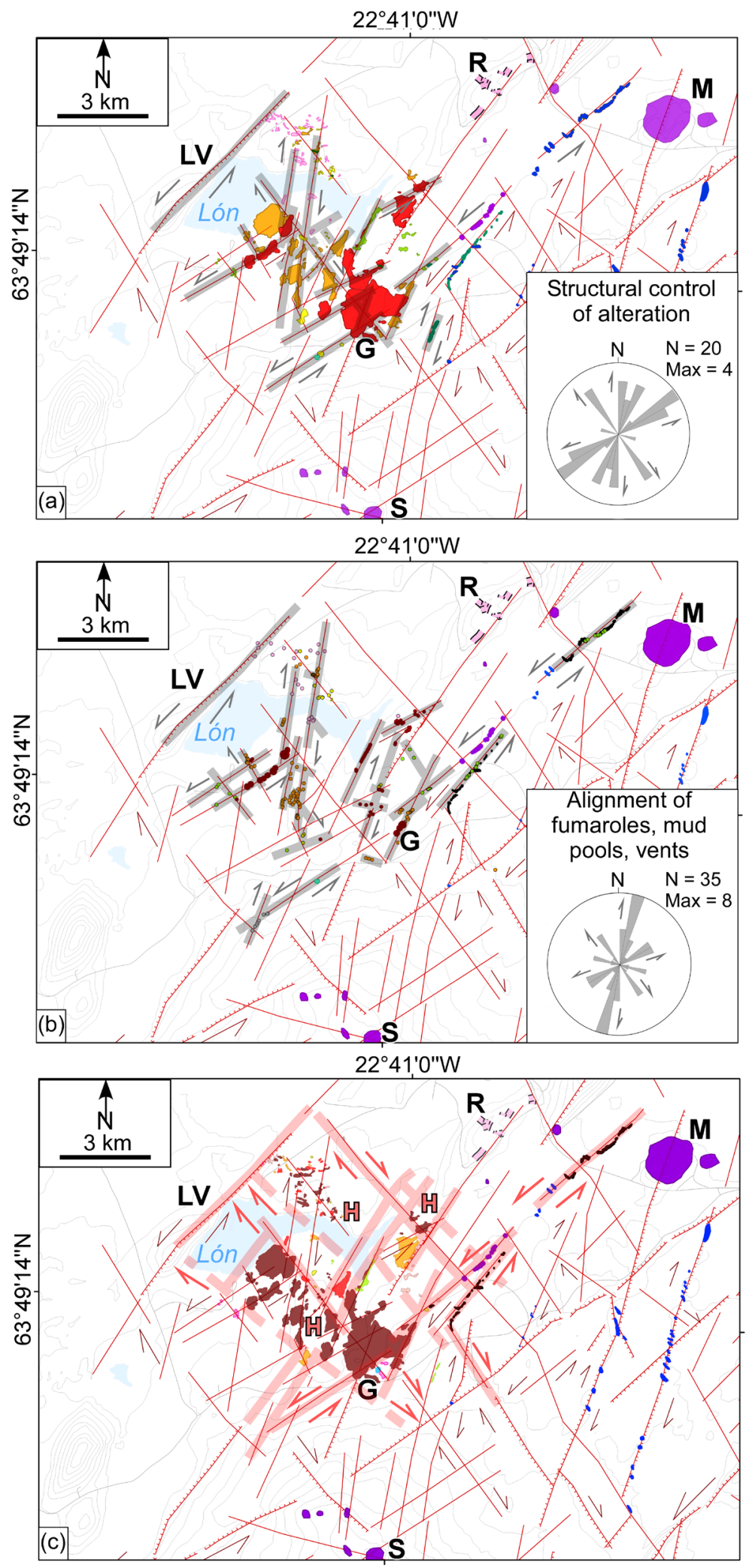

\section{Common legend}

Tectonic structures

- Crater and eruptive fissure

\& Dykes in hyaloclastites

- Push-up

Fault with dip-slip (bar toward downthrown block)

Undifferentiated or subtle fracture

a 7 Strike-slips: (a) Dextral

(b) Sinistral

Possible structures controlling geothermal activity and temperature distribution

Surface geothermal activity: (a) Alteration, (b) fumaroles, mud pots, steam

\section{a b Intense/fumarole, mud pots High/fumaroles, mud pots \\ Moderate/fumarole, steam Low/steam \\ Green moss/steam \\ Warm ground/steam \\ - Extinct silica sinter \\ - Surface ruptures with geothermal steam}

Measured surface temperature

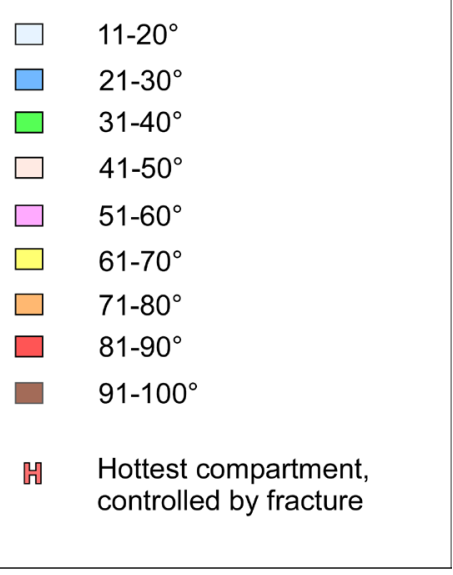

Figure 9. Tectonic control of the surface manifestations and soil temperature mapped in July-August of 2014. (a) Alteration map according to intensity with the highlight of the fractures likely controlling them, as well as the rose diagram of the strikes and motions of those host fractures. (b) Same for the fumaroles, mud pools and steam vents. (c) Soil temperature map and interpretation of the structures controlling their distribution. See text for the details of the interpretation. 

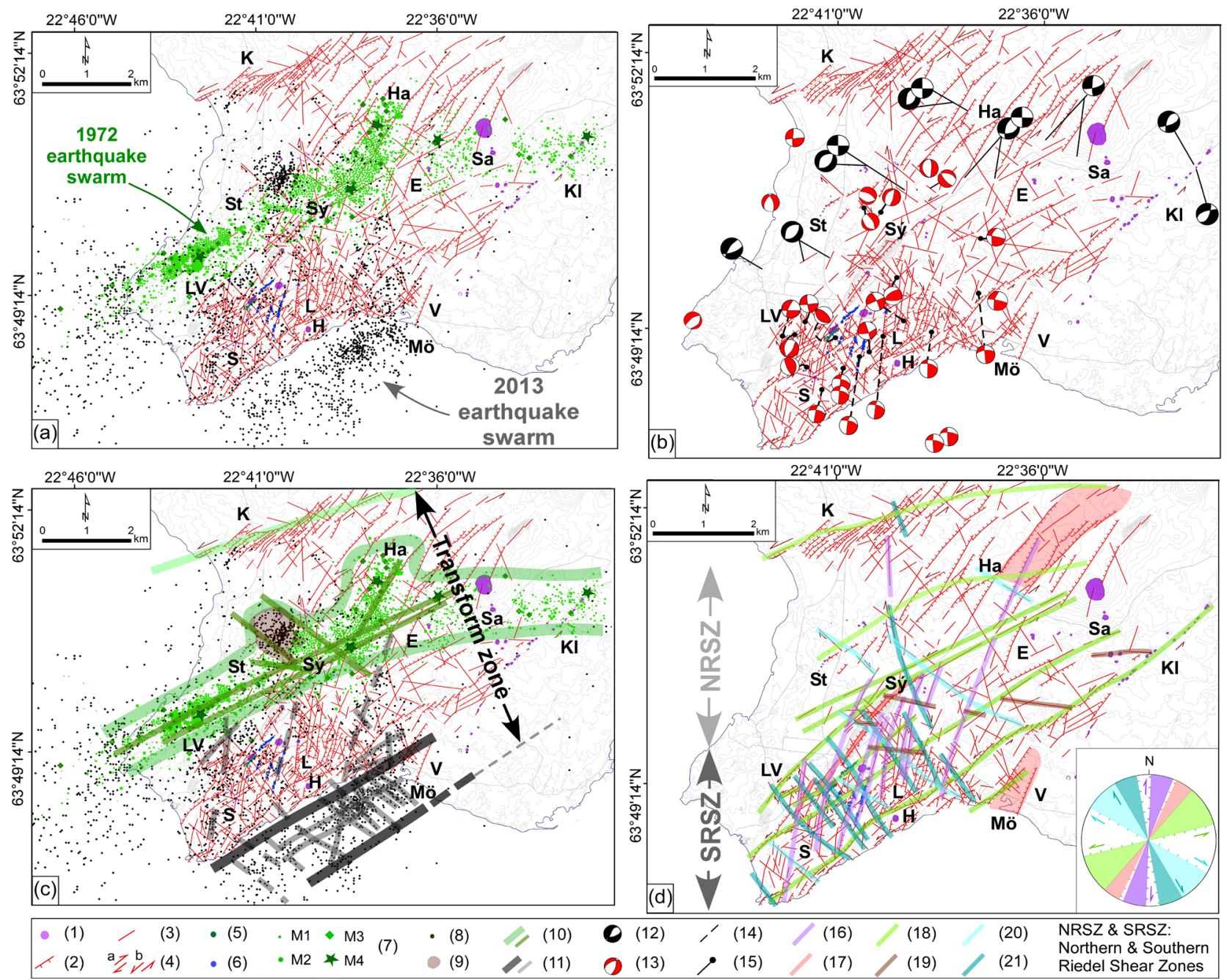

Figure 10. Correlation with earthquakes and interpretation. (a) Earthquakes of 1972 and 2013-2015 superimposed on the structural map. (b) Fault plane solutions (FPS) of both earthquakes. (c) Seismo-tectonic interpretation and the suggested minimum width of the transform zone. (d) Recall of the two Riedel shear zones and the main structures within them. Legend common to all figures: (1) Crater and eruptive fissures; (2) Dip-slip (bar towards downthrown block); (3) Unidentified fracture/subtle fracture trace; (4a) and (4b) Dextral and sinistral strike-slips; (5) Surface rupture of earthquakes with surface geothermal activity; (6) Push-ups; (7) The 1972 earthquakes and their magnitudes (after [107]); (8) Earthquakes of 2013-2015 (after [117]); (9) Highlight of induced earthquakes due to injection into well RN-34; (10) Outline of the 1972 earthquakes and interpretation of their main seismic lineaments compared to the fracture pattern; (11) Same correlation with the 2013-2015 earthquakes; (12) and (13) Respectively, FPS of the 1972 (after [107]) and 2013-2015 earthquakes (after [125]). Black and Red quadrants are for compression; (14) and (15) Lines (and circle) pointing to the possible ruptured fault matching the FPS of 1972 (after [107]) and the 2013 earthquakes (after [65]); (16) to (21) Highlights of the most significant N-S, NNE, ENE, E-W, WNW, and NW/NNW structural weak zones within the two Riedel shear zones (after [65]).

extend all the way to the shoreline. These zones are at Litla-Vatnsfell, from Melur to Rauðhólar, from south of Melur to north of Skálafell, from Klofningar to Háleyjabunga and Skálafell, and that of Mölvík (Figure 7(c)). The best example of ENE sinistral oblique-slip faults belonging to these zones are the fault segments from Klofningar to south of Skálafell, displaying a systematic right-stepping en échelon arrangement, along with some of the highest metre-scale dip-slips (Figure 4(a)). 

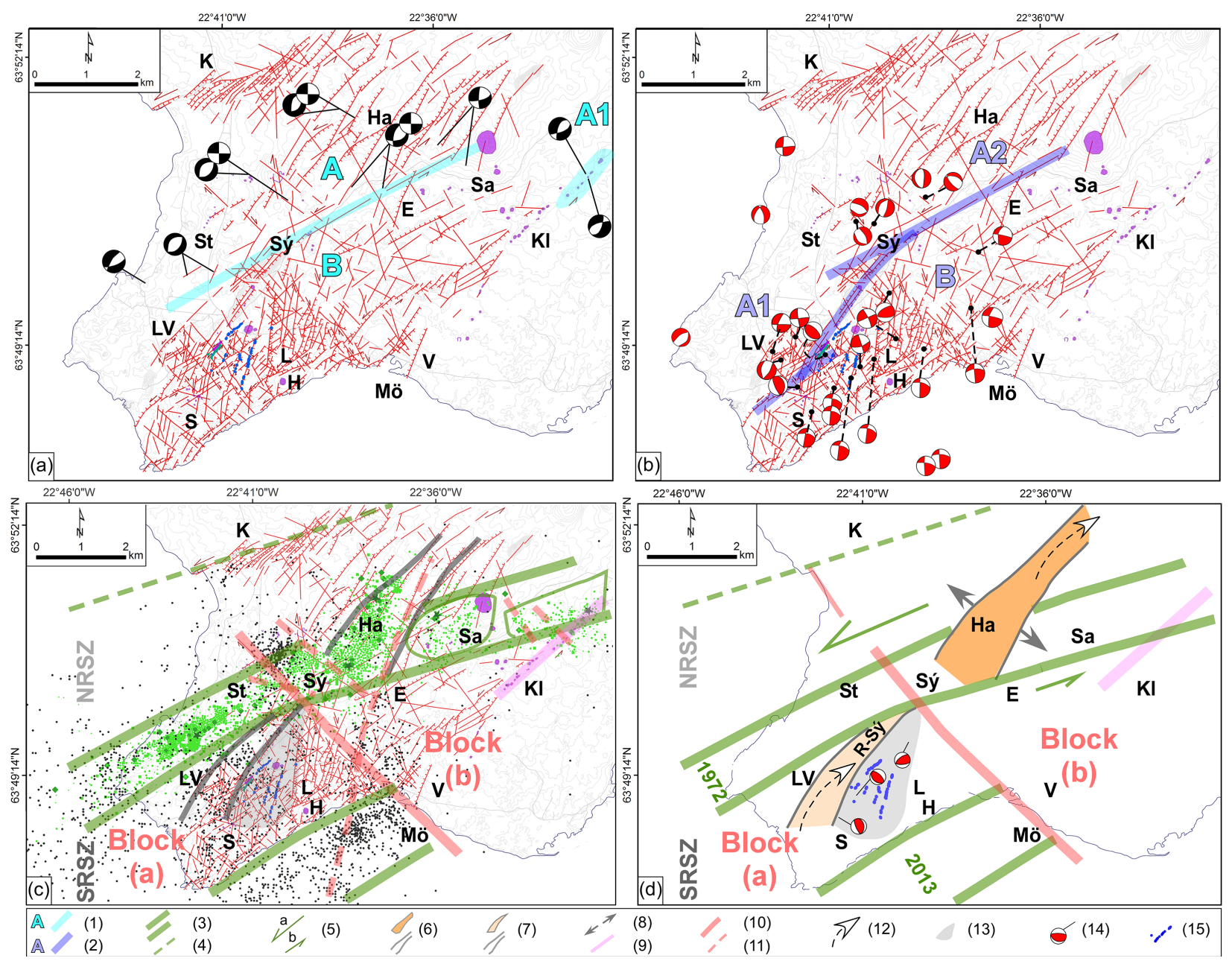

Figure 11. Seismo-tectonic interpretation of the fracture pattern (this study) and the earthquake swarms of 1972 (after [107]) and 2013 (after [116] and [125]). Base legend same as for Figure 10. Additional legend: (1) and (2) Respectively, the distribution of the FPS of the 1972 and 2013 earthquakes and the structures of the two Riedel shear zones acting as boundaries between the type of FPS. (3) Epicentral zone of the 1972 and 2013 earthquake swarms. (4) Possible northern boundary of the NRSZ passing through Kinn. (5a) More and (5b) less sinistral motion along the ENE deep structure of the 1972 earthquakes over a longer geological time period. This differential motion explains why a graben as wide as Haugur is formed to the north of the 1972 zone within the NRSZ and not in the SRSZ. (6) Outline of Haugur Graben. (7) Outline of Rauðhólar/Sýrfell structures. (8) Direction of extension across Haugur Graben. (9) Highlight of the eruptive fissure of Klofningar at Eldvörp. (10) Main WNW structure appearing in the seismic lineation within the 1972 swarm and extending into the SRSZ where it separates a highly fractured Block (a) from a less fractured Block (b). (11) Other seismic lineations. (12) Clockwise rotation of rift structures. (13) Area of compression due to clockwise rotation of the Rauðhólar/Sýrfell structure. (14) and (15) Respectively, location of reverse-slip FPS of 2013-2015 earthquakes and the push-ups concentrated in the area of compression due to rotation.

d) Three short WNW weak zones between northwest of Sýrfell and north of Rauðhólar, stretching to the shoreline (Figure 7(e)).

e) Four NW/NNW weak zones, stretching from land to shore, crossing Litla-Vatnsfell/Skálafell, Rauðhólar, Sýrfellsdrög to Melur and Háleyjabunga (Figure 7(f)).

The left-stepping en échelon arrangement of the WNW to NNW dextral oblique-slip segments is clear on maps but faults of these weak zones have $<5 \mathrm{~m}$ dip-slip on average, which is among the least dip-slip values. 


\subsubsection{Tectonic and Magmatic Fractures}

The significance of the fracture population for the style of deformation, and the structural setting of eruptions are analysed here.

a) The most relevant structures of each of the six sets (Figures 7 (a)-(f)) were combined and highlighted on a single structural map (Figure 8(a)). The emerging tectonic pattern is clearly that of an ENE Riedel shear zone with a higher number of sets and fractures than previously mapped on RP [16]. Two adjacent shear zones were observed and labelled as the Northern (NRSZ) and the Southern (SRSZ) Riedel shear zones (Figure 8(a)). Each of these zones is at least $3 \mathrm{~km}$ wide but their total dimension is unknown due to the limits of the study area in RP. The NRSZ has an overall strike of $N 74^{\circ} \mathrm{E}$ and the SRSZ N64 ${ }^{\circ} \mathrm{E}$. The northern boundary of the NRSZ coincides with a blend of NNE extensional faults and ENE sinistral oblique-slip faults crossing Kinn. The southern boundary of the NRZS and the northern boundary of the SRZS is the same. This boundary falls on the trace of very subtle ENE fractures that stretch from Sandfellshæð to Sýrfell and have a possible sinistral character (Figure 8(a)). The southern boundary of the SRSZ could be the ENE lineament passing through Mölvík. There, fresh ENE surface ruptures indicate recent reactivation (Figure 5(a)). In the NRSZ, the N-S set is lacking and there are fewer fractures belonging to the other sets, while the SRSZ is populated by a large number of fractures belonging to all the six sets (Figure 8(a)). The geothermal reservoir is in the western portion of the SRSZ. In the NRSZ, the Haugur Graben seems to stop on a smaller WNW fault to the north of Sýrfell, which is one of the reasons why this rift structure does not appear to continue as a wide graben in the SRSZ.

b) The second striking feature is the structural pathways of eruptions. The diametres of the eruptive edifices range from roughly a metre such as east of Rauðhólar (Figure 3(a) and Figure 5(b)) to $100-150 \mathrm{~m}$ for the crater at Sandfellshæð (Figure 2 and Figure 8(a)). Eruptions are generally considered to occur on rift extensional fractures in Iceland [88], and on RP [16]. Consequently, the main eruptive dyke and the possible heat source of the geothermal reservoir is likely to be attributed to the NNE structure of Rauðhólar/Sýrfell. However, the mapped dykes at Rauðhólar strike dominantly ENE, and secondarily N-S, NNE and WNW (Figure 4(d)), and are thus a mixture of extensional and shears fractures. Furthermore, a closer analysis of the structural map shows that the crater of Melur is on the trace of a N-S dextral oblique-slip fault, and the smaller craters to the east of Rauðhólar are aligned on an ENE lineation in the southwestward continuation of the ENE push-ups. The craters and the push-ups are arranged in right-stepping ENE en échelon segments similar to sinistral conjugate source faults of earthquakes (Figure 3(a)). Similarly, farther to the east, the eruptive fissures of Klofningar in Eldvörp are aligned ENE with a clear right-stepping en échelon arrangement in the continuation of the ENE oblique-slip fault passing through north of Mölvík and Háleyjabunga, and south of Skálafell (Figure 2 and Figure 8(a)). These examples show that an important number of the RP eruptions occurs along non-rift structures. 


\subsubsection{Dynamic and Kinematic Behaviours}

The concept of oblique rifting on RP where extension and shear motion occur in equal proportion was introduced by [123], although opinions diverge regarding the detailed dynamic behaviour. These fault modes are explained by permutations of the axes of two principal stresses in which normal faulting occurs when the maximum principal stress $\left(\sigma_{1}\right)$ is vertical, and strike-slip faulting when the intermediate principal stress $\left(\sigma_{2}\right)$ is vertical [124]. The minimum principal stress $\left(\sigma_{3}\right)$ remains the same in each case and is perpendicular to rift segments. Based on this idea, it is suggested that oblique rifting and magmatic phases alternate in $\mathrm{RP}$, and as the last eruption dates from the 13th century [106], RP presently undergoes oblique rifting [103]. Accordingly, the maximum compression is vertical during magmatic phases, shifting to horizontal (NE-SW) during oblique rifting and strike slip faulting, with the minimum compression perpendicular to the rift (NW-SE) in both phases. However, the earthquake swarms of 1972 [107] and 2013 [116] [125] demonstrate that normal, strike-slip and oblique-slip fault ruptures occur during the same earthquakes in a-magmatic phases (Figure 10(a) and Figure 10(b)). Stress inversion of focal mechanisms shows that the average direction of $\left(\sigma_{3}\right)$ on $\mathrm{RP}$ is $\mathrm{N} 120^{\circ} \mathrm{E}$, fitting well with the directions of the greatest extensional strain rate [126]. Analyses of aerial images and clay models of RP conclude that the predominant strike of eruptive fissures, non-eruptive fissures, and normal faults in the centre of the rift zone is perpendicular to $\mathrm{N} 133^{\circ} \mathrm{E}$ [16] and not to the plate spreading direction at $\mathrm{N} 103^{\circ} \mathrm{E}$ [64].

The observations presented here shed new lights on the above discussions. The major (Figure 8(a)) and secondary fractures (Figure 8(b)) mapped in this part of RP are dominantly shear fractures, combined with one set of extensional fractures, similar to the SISZ [127] and its immediate zone of influence in the Hreppar micro-plate [120]. In SISZ and the mapped area in RP, the N-S dextral and ENE sinistral conjugate source faults act respectively as (R') and (R), and the NNE set as (T), which is also parallel to rift. These sets along with the WNW/NW and E-W fractures accommodate together the sinistral motion of the transform zone. The stress field required to explain such a structure is more complex than previously discussed, but a part of the deformation can be explained kinematically. Four points reflect this:

a) In RP, dykes are observed to inject into NNE rift extensional fractures as well as into N-S, ENE and WNW shear fractures. Magma injection into shear fractures has been reported from other areas of Iceland under the influence of rift and transform zones such as west Iceland [86], Theistareykir onshore [128], and GOR offshore north Iceland [62]. Magma injection into shear fractures is relatively frequent although this mechanism receives less attention than magma injection into rift structures.

b) Within the SRSZ, the Litla-Vatnsfell and Rauðhólar/Sýrfell structures present a bend in their orientation from NNE to ENE. Rauðhólar/Sýrfell has two parallel narrow segments and Litla-Vatnsfell displays a single fault trace. Both 
structures have local metre-scale dip-slip and en échelon arrangements typical of sinistral motion. In case of Rauðhólar/Sýrfell, the segmentation could also result from the intersection with some of the WNW/NW weak zones (Figure 8(a)). The strikes of these structures change from $\mathrm{N} 35^{\circ} \mathrm{E}$ to $\mathrm{N} 47^{\circ} \mathrm{E}$ and to $\mathrm{N} 54^{\circ} \mathrm{E}$ for Litla-Vatnsfell, and from $\mathrm{N} 25^{\circ} \mathrm{E}$ to $\mathrm{N} 35^{\circ} \mathrm{E}$ to $\mathrm{N} 50^{\circ} \mathrm{E}$ for Rauðhólar/Sýrfell. This gradual change reflects a clockwise rotation of the rift structures at the approach of the ENE sinistral boundary between the two Riedel shear zones. Rotations of rift across transform segments are not rare and are also seen in north Iceland [129] and on the Iceland shelf to the south of RR [130].

c) Further discussion on the direction of $\left(\sigma_{3}\right)$ is necessary. Under a regional spreading at $\mathrm{N} 103^{\circ} \mathrm{E}$ [64], and assuming that $\left(\sigma_{3}\right)$ is perpendicular to the rift fissure swarm, pure extensional fractures should strike $\mathrm{N} 13^{\circ} \mathrm{E}$ (Figure $8(\mathrm{c})$ ), but this study and that of [16] show that fractures striking $\mathrm{N} 13^{\circ} \mathrm{E}$ are dextral oblique-slips. In fact, none of the shear fractures observed in this study can be explained by a single $\left(\sigma_{3}\right)$ perpendicular to rift because the N-S, ENE, WNW and $\mathrm{NW}$ sets have a wide strike-range, requiring a $\left(\sigma_{3}\right)$ at $\mathrm{N} 113^{\circ} \mathrm{E}$ to $\mathrm{N} 128^{\circ} \mathrm{E}$ (Figure $8(\mathrm{e}))$. The suggested variation in the direction of $\left(\sigma_{3}\right)$ is compatible with the results of [16] and [126], and also observed across SISZ [127]. Along with permutations in $\left(\sigma_{1}\right)$ and of $\left(\sigma_{2}\right)$, these results indicate that fluctuations occur also in the direction of $\left(\sigma_{3}\right)$.

d) The significance of the WNW to NNW fractures in Reykjanes is puzzling and their existence cannot be explained by stress fluctuations. The two sets act as secondary fractures within the SISZ where they display a possible sinistral motion [127]. In Reykjanes, these sets do not appear as second-order fractures because they have prominent trace and length and they display a dextral motion (Figure 8(e)). Prior to this study, a few WNW to NW fractures were pointed both on RR near Reykjanes [131] and onshore near the study area [111], and attributed to transfer/transform zones. However, these sets cannot belong to a second active WNW-NW transfer/transform zone since the transform zone strikes ENE on RP (Figure 1(b)). Furthermore, major WNW and NW structures are present as far north as in Snæfellsnes Volcanic Zone [121] and in the older lavas of west Iceland [122]. There, the structures are attributed to a Tertiary transform zone that was reactivated during the Quaternary [85] [86]. Although the origin of these sets cannot be resolved with the data at hand, a likely kinematic explanation could be that they act as horsetail splay structures (Figure $8(\mathrm{e}))$.

\subsubsection{Surface Geothermal Manifestations}

The surface alteration, fumaroles and mud pools, as well as soil temperature distribution are interpreted in light of the structural pattern (Figures 9(a)-(c)).

The mapped alteration above the reservoir is organised in two overall groups. The rare high alteration spots to the north of Lón are arranged in a left-stepping en échelon array along a N-S line similar to N-S dextral strike-slip surface ruptures (Figure 3(a) and Figure 6(d)). This N-S zone extends to the south of Lón 
where it is wider and it separates the areas of intense and high alterations (Figure 9(a)). The alignments and the changes in the degree of alteration in these zones coincide mostly with the ENE sinistral, N-S and NW dextral structures. In particular, the intense alteration occurs dominantly along the ENE set, while the high alteration is controlled by the NW set and by series of tightly parallel N-S strike-slip faults crossing the Lón from north to south (Figure 9(a)).

Although much smaller in size, the fumaroles, mud pools, and steam vents similarly appear on or at the intersection of fractures (Figure 9(b)). The most prominent fumaroles align on five parallel N-S segments, two of which stretch into the described N-S "high alteration zone" to the north of Lón. Other fumaroles, mud pools, and steam vents line up on the same ENE sinistral (Figure 6(e)) and NW dextral fracture segments of the alteration zones. A few align on the NNE segments of Rauðhólar (Figure 9(b)). Such manifestations are absent west of the Litla-Vatnsfell Fault, and the last steam vents to the east of the study area are aligned on the ENE push-ups and N-S sink-holes of the surface ruptures and not on the small crater row of east Rauðhólar (Figure 3(a), Figure 6(a) and Figure 6(b)). The ENE sinistral and N-S dextral segments are likely the structural barriers of the reservoir to the east and the last permeable structures into which the steam from the reservoir can circulate.

The highest soil temperatures $\left(91^{\circ}-100^{\circ} \mathrm{C}\right)$ appear in small spots to the north and east of Lón but mostly occur to the south of this lagoon (Figure 9(c)). Except for the N-S structures crossing the middle of Lón, temperature distribution is controlled by the same fracture sets as those governing the alteration and fumaroles. However, the dominant sets playing a role in the temperature distribution are different. The main areas with highest temperatures $\left(91^{\circ}-100^{\circ} \mathrm{C}\right)$ are constrained by the NW structures and the NNE segments of Rauðhólar. These structures isolate a small block where temperatures are $10^{\circ} \mathrm{C}$ to $20^{\circ} \mathrm{C}$ lower. The cooling of the soil beyond the central hot core seems to occur on the same structures as above, i.e., the Litla-Vatnsfell Fault to the west, and the ENE sinistral segments acting as the last structure where steam escapes from the reservoir to the east (Figure 6(a), Figure 6(b), Figure 9(b), Figure 9(c)). Additionally, the dominant WNW boundaries are those to the south of Rauðhólar and southwest of Lón (Figure 9(c)). The monitoring of soil temperature above the reservoir using a grid of $25 \mathrm{~m}$ interval [132] [133] shows a rapid fluctuation of surface temperatures between years. The suggested fracture sets controlling the surface geothermal manifestations are evident in the yearly independent monitoring.

\subsection{Correlation with Selected Data and Further Interpretation}

\subsubsection{The 1972 and 2013 Earthquakes}

Four earthquake swarms occurred in Reykjanes since the 1960's. The 1967 events had a magnitude up to $\mathrm{M}_{\mathrm{L}} 4.9$ [134] [135], and 5 - $8 \mathrm{~cm}$ oblique-slip on the fault at Valbjargargjá (Figure 2) [136] [137]. The 1972 swarm had 17.000 events, mostly at $2-5 \mathrm{~km}$ depth and $\mathrm{M}_{\mathrm{L}}$ up to 4 [107]. The 2006 swarm occurred south 
of Reykjanes geothermal field offshore, and that of 2013 took place in the same area and was well recorded by the network of HS Orka-ÍSOR and that of the Icelandic Meteorological Office (SIL). GPS and InSAR [119] revealed co-seismic displacements up to $3 \mathrm{~cm}$ in the 2013 events, but there was no significant influence on the geothermal field.

Although the 1972 and 2013 earthquakes have not been subject to relative relocation of hypocenters, the correlation of their seismic lineations (Figure 10(a)) and fault plane solutions (FPS) (Figure 10(b)) with the structural map (Figures 10(c)-11(d)) yields critical information:

a) The epicentral zone of the 1972 earthquake swarm is $\sim 1.2$ to $\sim 2.6 \mathrm{~km}$ wide and its overall ENE trace coincides with the area separating the NRSZ and the SRSZ (Figure 10(a), Figure 10(c), Figure 10(d)). This swarm acts as the boundary of the two ENE Riedel shear zones. The subtle $\mathrm{N} 65^{\circ} \mathrm{E}$ fractures with possible sinistral motion to the north of Sýrfell could be the discreet surface expression of this deep earthquake swarm (Figure 10(a) and Figure 10(c)). The 2013 swarm is contained in a $\sim 1.5 \mathrm{~km}$ wide band that includes the suggested southern boundary of the SRSZ (Figure 10(d)), including the fresh ENE ruptures found during the 2014 field mapping (Figure 5(a)). Analysis of the 2013-2015 earthquakes [117] reveals an aseismic body under the geothermal field (Figure 10(a)) above the brittle-ductile boundary of $6 \mathrm{~km}$. The body is attributed to episodic activity, pore pressure reduction due to production, or to a hot body $\left(>600^{\circ} \mathrm{C} \pm 100^{\circ} \mathrm{C}\right)$ at depth.

b) The epicentral zone of the 2013 earthquake swarm is short and strikes $\mathrm{N} 60^{\circ} \mathrm{E}$, but that of the 1972 swarm could be interpreted as striking $\sim \mathrm{N} 60^{\circ} \mathrm{E}$ up to Haugur Graben and bending to $\sim \mathrm{N} 80^{\circ} \mathrm{E}$ from there to Klofningar with two clusters of earthquakes shooting off its middle (Figure 10(c)). Seismic lineations align on three sets within the 2013 swarm: (1) ENE offshore; (2) WNW-NW offshore in the continuation of the dextral weak zones of the SRSZ (Figure 5(d) and Figure 5(g)); (3) N-S from sea towards Haugur Graben on the trace of the weak zone of Langihryggur (Figure 10(c)). Within the SRSZ onshore, seismic lineations align on two additional N-S dextral oblique-slip faults. They are on some of the N-S faults with push-ups to the east of Rauðhólar, and the N-S structure crossing the middle of Lón (Figure 10(c)). These seismic lineations appear on faults, which have already been interpreted as weak zones based on structural features (Figure 7, Figure 8(a) and Figure 10(d)). In addition to the lineations coinciding with the subtle ENE sinistral fractures of north Sýrfell, earthquakes do cluster on three additional structures within the 1972 swarm. Clockwise on Figure 10(c), one of the clusters appears as a short E-W/WNW lineation immediately to the north of Sýrfell. It is in the continuation of an E-W fracture mapped farther east of Sýrfell. A second earthquake cluster protrudes with an overall WNW elongation farther north and seems to be bounded by the mapped WNW dextral strike-slip segments there. The third cluster is the most prominent and aligns $\mathrm{N} 25^{\circ} \mathrm{E}$ at the exact location of Haugur 
Graben (Figure 10(c)).

c) The FPS of the 1972 swarm are an average of several earthquakes, and their suggested fault traces [107] fit our mapped structures (Figure 10(b)). These FPS are normal, strike- and oblique-slips, in absence of reverse-slip. When strikeand normal-slip FPS are adjacent, strike-slips are interpreted as being above 3 $\mathrm{km}$ depth and normal-slips below that depth [107]. The 2013-2015 FPS are at 1.6 to $6 \mathrm{~km}$ depth, with $\mathrm{M}_{\mathrm{L}} 0.61$ to 3.08, oblique-slip is rare but three reverse-slip FPS exist [117] [125]. Strike-slips in the FPS are on N-S dextral and/or E-W sinistral fractures, while normal and reverse-slip occur on $\mathrm{N} 10^{\circ} \mathrm{E}, \mathrm{N} 40^{\circ} \mathrm{E}, \mathrm{N} 110^{\circ} \mathrm{E}$, and $\mathrm{N} 155^{\circ} \mathrm{E}$ planes (Figure 10(b)). No apparent relation exists between the depths, magnitudes and mechanisms of these FPS. The FPS from 2013-2015 were accurately positioned on topographic map but without suggested fault traces [117] [125]. The location and motions of 23 of the 2013-2015 FPS correlate well with the strike and motions of the mapped fractures (Figure 10(b)). Furthermore, the correlation of all FPS with the mapped structures shows that the 1972 earthquake swarm occurred only in area (A) in the NRSZ, as well as on the ENE eruptive fissure of Klofningar (Figure 11(a)). This confirms the suggestion that the eruption there occurred on oblique-slip fault segments. The distribution of the 2013-2015 earthquakes, on the other hand, is influenced by three of the major weak zones (Figure 11(b)). A blend of dip-slip and strike-slip FPS are in areas (A1) to the west of Rauðhólar in the SRSZ. Almost all of the dip-slip FPS are located in area (A2) of the NRSZ. On the other hand, all reverse-slip and almost all strike-slip FPS are concentrated in area (B) of the SRSZ (Figure 11(b)). These dominant types of FPS are clearly separated by the major structures identified earlier, i.e., the ENE boundary between the NRSZ and the SRSZ, the rotated segments of Rauðhólar/Sýrfell, and the western portion of the ENE fault to the south of Lón (Figure 11(b)).

\subsubsection{Seismo-Tectonic Features of a Few Regional Structures}

The above correlations (Figure 10) with earthquakes allow five additional seismo-tectonic interpretations of regional structures (Figure 11).

a) The existence of the NRSZ and SRSZ and their roles in the distribution of earthquakes and their FPS suggest that the transform zone consists at minimum of two adjacent ENE Riedel shear zones. Consequently, the transform zone is at least $7.5 \mathrm{~km}$ wide (Figure 10(c)), and is much wider than previously thought. The SRSZ is presently the most seismically active part of the transform zone as indicated by the 2013 swarm.

b) The epicentral zone of the 1972 earthquakes can be explained without a bend and as a single zone of N70 ${ }^{\circ} \mathrm{E}$ with an average width of $1.3 \mathrm{~km}$ (Figure 11(c) and Figure 11(d)). Most earthquake clusters are within this ENE zone, including those of Klofningar-Eldvörp, which seem organised in right-stepping en échelon segments indicative of sinistral motion (Figure 11(c)). Within this ENE zone, local earthquakes also align on short WNW planes (Figure 11(c)). A rare example of reactivation of a rift structure by the transform zone appears to be 
the NNE earthquake clusters shooting off the ENE zone into the NNE Haugur Graben. As this earthquake cluster is confined to the NNE graben, it indicates that during episodes of transform faulting, earthquakes "leak" into extensional rift structures and reactivate them (Figure 11(c)).

c) In addition to the individual weak zones interpreted earlier, one particular WNW structure also contributes to block compartmentalisation, but at a more regional scale (Figure 11(c) and Figure 11(d)). Haugur Graben merges with the ENE shear zone of 1972 earthquakes and the southern border of the graben stops on one of the described WNW seismic lineations to the north of Sýrfell (Figure 11(c)). To the southwest of this WNW structure, another parallel subtle WNW seismic lineation exists and coincides with the trace of many of mapped WNW weak zones that extend from Sýrfell southeast to Mölvík (Figure 11(c)). This particular WNW structure separates the highly fractured Block (a) from the lesser deformed Block (b). The geothermal reservoir lies in the heavily broken Block (a) within the SRSZ.

d) The bend of the Rauðhólar/Sýrfell segments and the Litla-Vatnsfell Fault from NNE to ENE clearly occurs across the ENE boundary between the two Riedel shear zones and is compatible with sinistral motion of this structure. Compression is expected in association with such clockwise rotation. The evidence for this compression appears as the dominance of push-ups concentrated in the eastern compartment of the rotated Rauðhólar/Sýrfell structure as well as the location of the three reverse-slip FPS of the 2013-2015 earthquakes (Figure 11(b) and Figure 11(d)). Reverse-slip in Iceland is not a result of regional compression by shortening but occurs due to local bends of steeply-dipping normal faults or in association with dyke injections [138]. Additionally, about 20\% $30 \%$ of seismic events in the western part of RP show reverse-slip mechanism, and have been explained as displacements on non-optimally oriented faults or block rotations [139]. The localised push-ups and reverse-slip FPS in the SRSZ show an example of compression associated with such rotation. More rotated rift structures similar to Rauðhólar/Sýrfell and Haugur Graben should be present on RP within the transform zone (Figure 11(c) and Figure 11(d)).

e) A wide graben similar to Haugur is absent from the SRSZ likely because the amount of sinistral shift in the NRSZ has been larger over hundreds or thousands of years than in the SRSZ. This greater displacement in the NRSZ led to graben formation. The GPS measurements of a 6-year period (2000-2006) indicate the direction of differential horizontal movement across the transform zone [104], but this time period is much shorter than the geological time necessary for the graben formation.

\subsection{3. $\mathrm{CO}_{2}$ Surface Flux}

Along with an overall increase in the $\mathrm{CO}_{2}$ flux [115], there has been a steady increase in the extent and activity of surface geothermal manifestations. This increase occurred since the start of the power plant, but can also be attributed to seismicity [115] [132]. As an example of yearly fluctuations, $\mathrm{CO}_{2}$ flux changed 
from 51.4 tons in 2013 to 78.5 tons in 2014 [115], and steam flow estimated from all fumaroles increased from $0.82 \mathrm{~kg} / \mathrm{s}$ in 2004 to $6-7 \mathrm{~kg} / \mathrm{s}$ in 2007 [132]. After an episode of earthquakes in 2014, a few mud pools erupted and a powerful fumarole appeared to the west of Gunnuhver. Based on local well discharge and visual comparison with the steam discharge of Gunnuhver in 2014, the steam flow of the new fumarole was estimated at $18-19 \mathrm{~kg} / \mathrm{s}$.

Surveys of 2005, 2006, 2008, and 2011 show the $\mathrm{CO}_{2}$ flux to the south of Lón (Figures 12(a)-(d)). The measurements of 2012 and 2014 included an area to the north and east of the lagoon (Figure 12(e) and Figure 12(f)). Despite minor changes in the shape of the areas, the overall changes in the $\mathrm{CO}_{2}$ flux in 2005, 2006, 2011, 2012, and 2014 [115] occur within blocks bounded by tectonic fractures. These blocks are bounded dominantly by WNW dextral and ENE sinistral strike- and oblique-slip fractures, and secondarily by the N-S dextral strike- and oblique-slip faults and the NNE extensional structures of Rauðhólar. Even if the measured $\mathrm{CO}_{2}$ flux is more subtle in 2008 (Figure 12(c)), the same structural control is visible among the faint distributions of the gas during that year.

Overall, these are the same structures as identified locally and regionally from other criteria above (Figure 8(a)). As example, the N-S, NNE, ENE, and WNW-NW controlling the surface geothermal manifestations, temperatures and $\mathrm{CO}_{2}$ flux (Figure 9 and Figure 12) also ruptured during the 2013 swarm as shown by the FPS of area (A1) (Figure 11(b)).

\subsubsection{Carriers and Barriers to Tracer Flow}

Prior to this structural analysis of tracer recovery, alteration and temperature from a fewer wells than in the present study were used to determine the internal reservoir characteristics [111]. Those results indicated a shallow (200 m) NE upflow zone stretching from southeast of Lón to Sýrfellsdrög, and a N-S structure crossing the middle of Lón. These two structures were also suggested by TEM resistivity anomalies [140].

To study the flow channels and fracture permeability in the reservoir, tracers were injected into two production wells, i.e., 2,7-NDS into well RN-20b in August 2013, and 2-NS into RN-33 in January 2014 (Figures 13(a)-(d)). At the time of these investigations, the tracer from RN-20b took between 77 and 133 days to reach the monitored wells, and that from RN-33 between 24 to 333 days (Table 1, Figure 13(a) and Figure 13(c)).

Data from the tracer experiment were summarised by [141], supporting the existence of the hypothesised N-S and NE zones. From these studies, the N-S zone was deemed semi-permeable, and the NE permeable structure was placed slightly north of that suggested by [111]. Both these interpretations were made without the benefit of the present structural interpretation.

In this study, three datasets were used for the structural interpretation of tracer flow paths. These are: (a) results of the distribution and timing of tracer arrival (Table 1) in wells [118], (b) the pressure drawdown at $1600 \mathrm{~m}$ depth (Figure 13(a) and Figure 13(c)) calculated for the period of 2008 to 2012 (courtesy of Ómar Sigurðsson, HS Orka, 2014), and (c) the structural map. The tracer is 

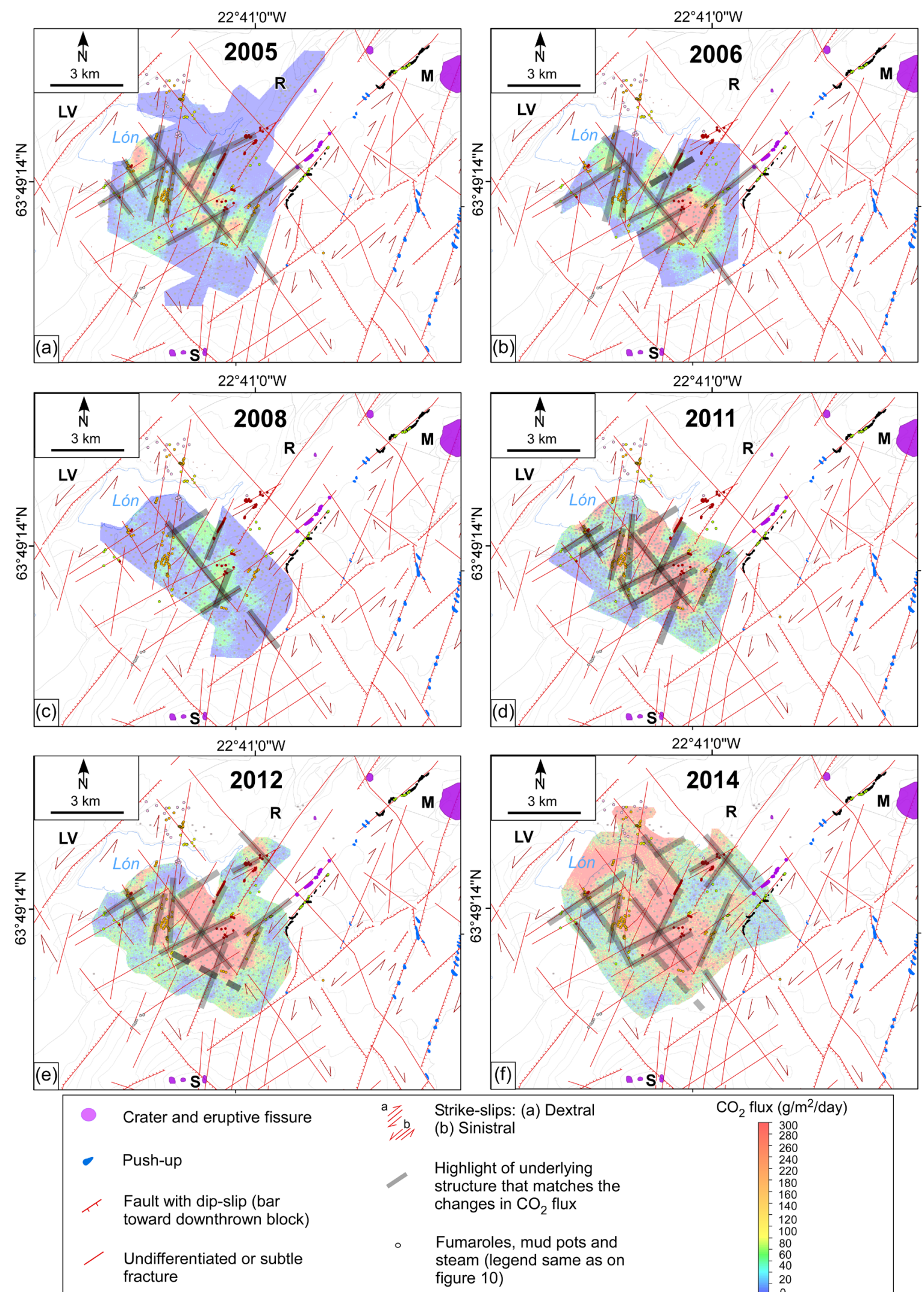

$\mathrm{CO}_{2}$ flux $\left(\mathrm{g} / \mathrm{m}^{2} / \mathrm{day}\right)$

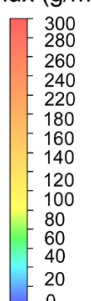

Figure 12. $\mathrm{CO}_{2}$ surface flux (after [115]), and our interpretation of its tectonic control using the suggested fracture pattern in this study. The year of $\mathrm{CO}_{2}$ measurement is on each figure. 

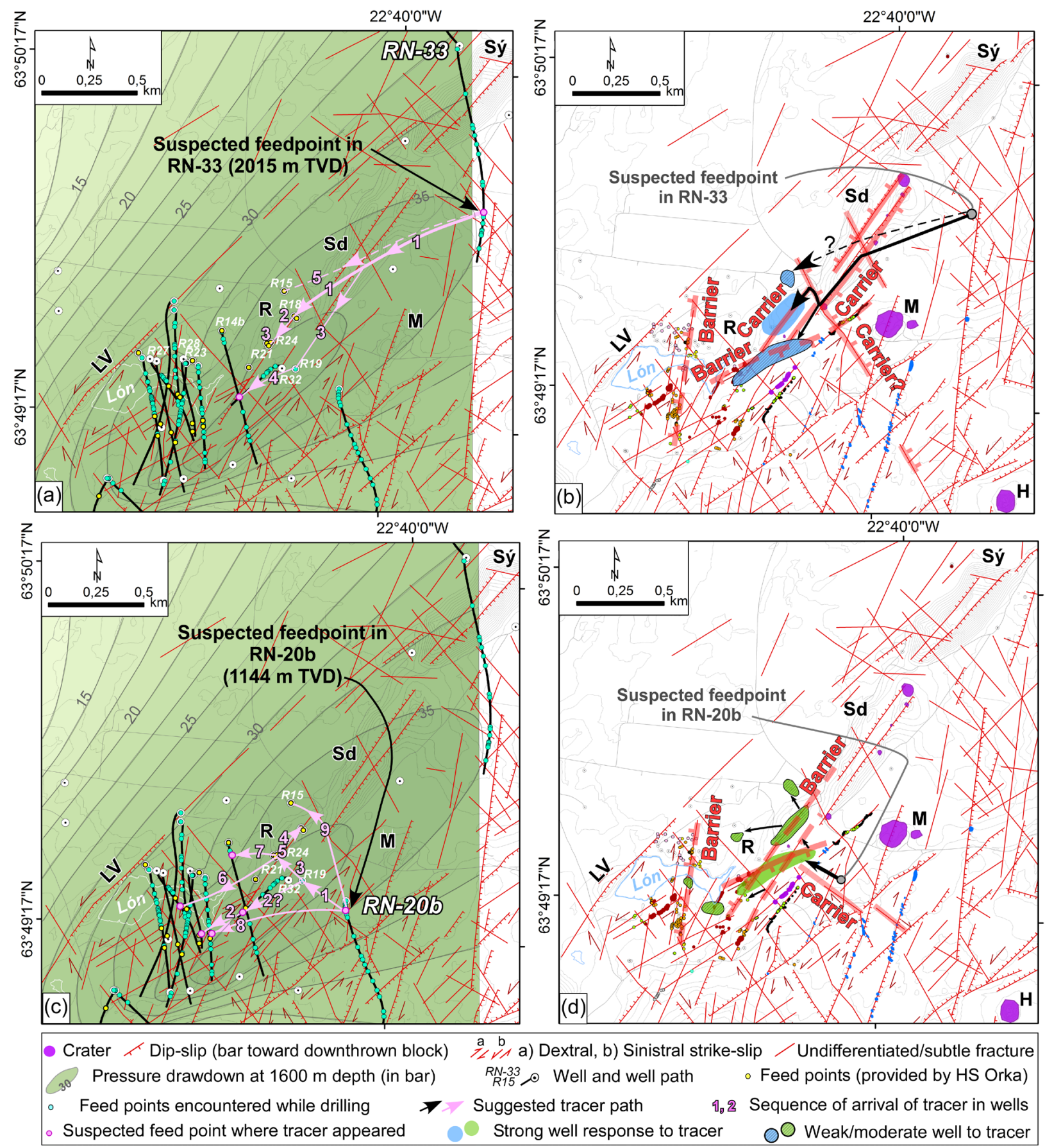

Figure 13. Structural interpretation of the tracer flow paths in terms of carrier and barrier structures. (a) The arrival sequence of tracer from well RN-33, and (b) the interpreted structural paths based on the sequence and order of tracer arrival, the amount of tracer, and the depth of the receiving feedpoint of the tracer. The receiving feedpoints are all above the depth of tracer injection. (c) and (d) The same for well RN-20b. See Table 1 for detailed information regarding these parametres.

assumed to have entered the formation at the depths of $1180 \mathrm{~m}$ (MD) in RN-20b and $2250 \mathrm{~m}(\mathrm{MD})$ in $\mathrm{RN}-33$ [118]. The rate of tracer propagation was calculated from its first arrival in wells. Overall, tracer moved faster from RN-33 than from $\mathrm{RN}-20 \mathrm{~b}$ (Table 1), and a large part of the injected water (and tracer) dispersed and diffused through the reservoir outside of direct flow channels [118]. 
Table 1. Base data used as parametres for the structural interpretation of tracer flow paths. Note that our selected tracer arrivals are feed points above the feed point of injected tracer (all depths in TVD). The question mark for the arrival of tracer from RN20B to $\mathrm{RN}-32$ is because the latter well did not produce until 220 days after the injection and then the tracer showed up with a strong signal.

\begin{tabular}{|c|c|c|c|c|c|c|c|c|}
\hline $\begin{array}{l}\text { Tracer } \\
\text { injected }\end{array}$ & $\begin{array}{l}\text { Depth of main } \\
\text { feedpoint in injector } \\
\text { well according } \\
\text { to spinner }\end{array}$ & $\begin{array}{c}\text { Tracer } \\
\text { detected }\end{array}$ & $\begin{array}{l}\text { Depth of feedpoint } \\
\text { in receiver well }\end{array}$ & $\begin{array}{c}\text { Travel time } \\
\text { of tracer } \\
\text { (days) }\end{array}$ & $\begin{array}{l}\text { Minimum } \\
\text { horizontal speed } \\
\text { of tracer ( } \mathrm{m} / \text { day) }\end{array}$ & $\begin{array}{l}\text { Tracer arrival } \\
\text { to feedpoint }\end{array}$ & $\begin{array}{l}\text { Tracer } \\
\text { amount }\end{array}$ & Path \\
\hline \multirow[t]{5}{*}{ In $\mathrm{RN} 33$} & $1984.05 \mathrm{~m}$ & RN-18 & $1747 \mathrm{~m}$ & 77 days & 13.7 & Goes up in $1747 \mathrm{~m}$ & Strong & 1 \\
\hline & & $\mathrm{RN}-21$ & $\begin{array}{c}716 \mathrm{~m} ; 1280 \mathrm{~m} \\
1575 \mathrm{~m}\end{array}$ & 91 days & 13.7 & Goes up in $1575 \mathrm{~m}$ & Moderate & 2 \\
\hline & & $\mathrm{RN}-19$ & $1700 \mathrm{~m}$ & 96 days & 12.5 & Goes up in $1700 \mathrm{~m}$ & Weak & 3 \\
\hline & & $\mathrm{RN}-24$ & $710 \mathrm{~m} ; 1305 \mathrm{~m} ; 2050 \mathrm{~m}$ & 96 days & 13 & Goes up in $1305 \mathrm{~m}$ & Moderate & 3 \\
\hline & & $\mathrm{RN}-32$ & $1005 \mathrm{~m}$ & 112 days & 17.5 & Goes up in $1005 \mathrm{~m}$ & Weak & 4 \\
\hline $\begin{array}{c}\text { Tracer } \\
\text { injected }\end{array}$ & $\begin{array}{c}\text { Depth of main } \\
\text { feedpoint in well } \\
\text { according to spinner }\end{array}$ & $\begin{array}{l}\text { Tracer } \\
\text { detected }\end{array}$ & $\begin{array}{l}\text { Depth of feedpoint } \\
\text { in receiving well }\end{array}$ & $\begin{array}{l}\text { Travel time } \\
\text { of tracer } \\
\text { (days) }\end{array}$ & $\begin{array}{l}\text { Minimum } \\
\text { horizontal speed } \\
\text { of tracer (m/day) }\end{array}$ & $\begin{array}{l}\text { Tracer arrival } \\
\text { to feedpoint }\end{array}$ & $\begin{array}{c}\text { Tracer } \\
\text { amount }\end{array}$ & Path \\
\hline \multirow[t]{9}{*}{ In $\mathrm{RN} 20 \mathrm{~B}$} & $1144 \mathrm{~m}$ & $\mathrm{RN}-19$ & $790 \mathrm{~m} ; 1730 \mathrm{~m}$ & 24 days & 10.8 & Goes up to $790 \mathrm{~m}$ & Strong & 1 \\
\hline & & $\mathrm{RN}-28$ & $892.1 \mathrm{~m}$ & 68 days & 11.6 & Goes up in $892 \mathrm{~m}$ & Moderate & 2 \\
\hline & & $\mathrm{RN}-21$ & $716 \mathrm{~m} ; 1280 ; 1575 \mathrm{~m}$ & 70 days & 6.2 & Goes up to $716 \mathrm{~m}$ & Moderate & 3 \\
\hline & & $\mathrm{RN}-18$ & $\begin{array}{l}826 \text { m (medium feedpoint); } \\
1747 \text { m (main feedpoint) }\end{array}$ & 77 days & 5.8 & Goes up to $826 \mathrm{~m}$ & Weak & 4 \\
\hline & & $\mathrm{RN}-24$ & $710 \mathrm{~m} ; 1305 \mathrm{~m} ; 2050 \mathrm{~m}$ & 85 days & 5.2 & Goes up to $710 \mathrm{~m}$ & Weak & 5 \\
\hline & & $\mathrm{RN}-27$ & $887.01 \mathrm{~m}$ (total loss); $895.63 \mathrm{~m}$ & 91 days & 10.7 & Goes up to $895 \mathrm{~m}$ & Weak & 6 \\
\hline & & $\mathrm{RN}-23$ & $1046 \mathrm{~m} ; 1110 \mathrm{~m}$ & 147 days & 5.9 & Goes up to $1110 \mathrm{~m}$ & Weak & 8 \\
\hline & & $\mathrm{RN}-32$ & $1005 \mathrm{~m}$ & $\begin{array}{l}\text { Before } \\
220 \text { days }\end{array}$ & $?$ & Goes up to $1005 \mathrm{~m}$ & Strong & $?$ \\
\hline & & RN-15 & $970 \mathrm{~m} ; 1720 \mathrm{~m} ; 2395 \mathrm{~m}$ & 333 days & 1.8 & Goes up to $970 \mathrm{~m}$ & Weak & 9 \\
\hline
\end{tabular}

The structural interpretation of tracer flow paths took into account these criteria: travel time, sequence of tracer arrival from injection well to the receiving well, the possible directions for such flow, the amount of tracer recovered, depth of the receiving feeders, the buoyancy of tracer, and the pressure drawdown. Where a receiving well had more than one feeder, the shallower feeder was chosen (Table 1) because colder injected tracer water is quickly heated by the hot formation and, therefore, drawn laterally and upwards into the zone of lowest pressure.

Figure 13(a) and Figure 13(c) summarise the travel paths and arrival sequences of tracer from RN-33 and RN-20b to individual wells. Figure 13(b) and Figure 13(d) show the interpreted structures that likely facilitated (or hampered) tracer flow based on their strong, moderate or weak concentration in the 
receiving wells (Table 1 ).

The tracer from RN-33 flowed from east-northeast towards the west-southwest and appeared successively along paths (1) to (5) without going farther than east of Lón (Figure 13(a) and Figure 13(c), Table 1). The tracer likely travelled first along two sets of carrier structures, i.e., the NNE segments of Rauðhólar/Sýrfell and a NW-striking fault, resulting in a high concentration and rapid appearance in wells just north of Rauðhólar (Figure 13(a) and Figure 13(b)). The fact that the tracer appeared later and in less concentration just to the south of Rauðhólar may be explained by the presence of the ENE fault along the trace of the push-ups. This ENE fault likely dips to the southeast thus acting as barrier to flow from RN-33 coming from the northeast. The longest tracer travel time and minimum concentration occurred in well $\mathrm{RN}-15$ located in the footwall of the NW-striking fault. The explanation for these occurrences is that the NW fault likely dips to the northeast. This structure facilitates fluid flow on its hanging wall but hampers the flow to its footwall. A second possible cause could be that the westernmost NNE segment of Rauðhólar/Sýrfell dips to the northwest and acts as a structural barrier to the tracer flow coming from the northeast (Figure 13(a) and Figure 13(b)). Finally, no tracer was found in the western half of the geothermal field. It is suggested that there is a N-S structure dipping to the west crossing the middle of Lón and hindering tracer flow. This barrier is in the same location as the series of N-S segments identified by the analysis of surface geothermal manifestations and $\mathrm{CO}_{2}$ surface flux (Figure 9, Figure 12, Figure 13(a) and Figure 13(b)).

As to the test from well RN-20b (Figure 13(c)), the tracer flowed from east to west and northwest, appearing successively along paths (1) to (9). Evidence of tracer was not detected farther west than the middle of Lón (Figure 13(c) and Figure 13(d), Table 1). The tracer first travelled along a WNW segment (path 1) and arrived quickly and in high concentration at the hanging wall of the ENE fault (Figure 13(c) and Figure 13(d)). This is the same ENE fault that acted as a barrier in the case of the flow from RN-33. The tracer from RN-20b then travelled southwest (path 2) where it appeared with lower concentration in well $\mathrm{RN}-28$. This well is located in the hanging wall blocks of both the ENE fault and the NNW segments of Rauðhólar. The tracer travelling along the paths (3) to (7) and (9) to the west and northwest arrived with much lower concentration and later in wells located in another compartment bounded by the NNE Rauðhólar/ Sýrfell, the ENE fault and the N-S barrier (Figure 13(c) and Figure 13(d)). The weak tracer signals there are likely caused by the same structural features as mentioned above, which are the dip directions of the ENE fault towards the southeast, and that of the NNE segment of Rauðhólar to the west, both acting as semi barriers. The flow to this compartment, however, could have occurred along another WNW segment belonging to the carrier structure of path (1). Similar to RN-33, no tracer from RN-20b was found in the wells located on the western half of the geothermal field and the reason is likely the existence of the 
N-S barrier structure there.

These analyses indicate that the same structure can act either as a carrier or barrier to flow, depending on the provenance of incoming flow and the dip direction of the fault.

\subsubsection{Pressure Drawdown, Subsidence and Reservoir Recharge}

In this section, the structural control of the pressure drawdown, the subsidence revealed by InSAR, and the direction of fluid recharge towards the reservoir (Figure 14(a) and Figure 14(b)) are analysed.

a) The geothermal reservoir has been subject to a pressure decline due to production, which value was assessed for the period of 2008 to 2012 (Figure 14(a)). The drawdown at $1600 \mathrm{~m}$ depth corresponds to the difference between the reservoir pressure before the start of large-scale production in Reykjanes and the year 2012. The pressure drop is as high as -40 bars in the centre of the geothermal field, decreasing gradually to -10 bars some $1.5 \mathrm{~km}$ away from the centre of production (Figure 14(a)). Although the analysis of the 2013 earthquakes shows a local aseismic body under the centre of the production field [117], there is no clear relation between the distribution of the 2013-2015 earthquakes and the general shape of the pressure drawdown (Figure 14(a)). The pressure drawdown has an overall NE elongation and is mostly confined to the SRSZ, banking against the ENE area of the 1972 earthquake swarm (Figure 14(a)). Both the shape and the detailed changes in the isolines of pressure drawdown are governed by the structures identified from the seismo-tectonic and the structural analysis of the geothermal reservoir. The centre of the drawdown occupies a narrow NNE zone where the -40 bars isolines align on the NNE segments of Rauðhólar/Sýrfell. The adjacent isolines of -30 to -37.5 bars, however, are oriented ENE and not NNE (Figure 14(a)). More precisely, the -30 bar isoline matches the trace of the Litla-Vatnsfell Fault to the northwest. To the southwest, the isolines of -37.5 and -35 bars coincide with the ENE sinistral surface ruptures of earthquakes, which are the last structure to the east from which steam escaped from the reservoir during the 2014 field mapping [65]. Within the western half of the pressure drawdown area, the isolines of -35 to -25 bars bend locally from ENE to N-S, exactly on the traces of the N-S dextral faults crossing the middle of Lón (Figure 14(a), Figure 15(a), Figure 15(b)).

b) The effect of the drawdown due to reservoir fluid extraction (Figure 14(a)) is also visible as land subsidence between 2009-2013 on InSAR images (Figure 14(b)) [119], as well as in gravity and GPS data [142]. The InSAR images (TerraSAR-X and TanDEM-X radar satellites) show a $3 \mathrm{~km}$ wide elliptical subsided area with an overall NE/ENE-SW/WSW elongation (Figure 14(b)) roughly matching the area of pressure drawdown (Figure 14(a)). The vertical subsidence rate coinciding with the centre of the production zone is on average $43 \mathrm{~mm} / \mathrm{yr}$, and the subsidence totals $20 \mathrm{~cm}$ between 2009 and 2013. The horizontal ground motion is up to $15 \mathrm{~mm} / \mathrm{yr}$ towards a relatively narrow NNE-SSW zone in the centre of the reservoir. Although the overall subsided area is wider on InSAR 


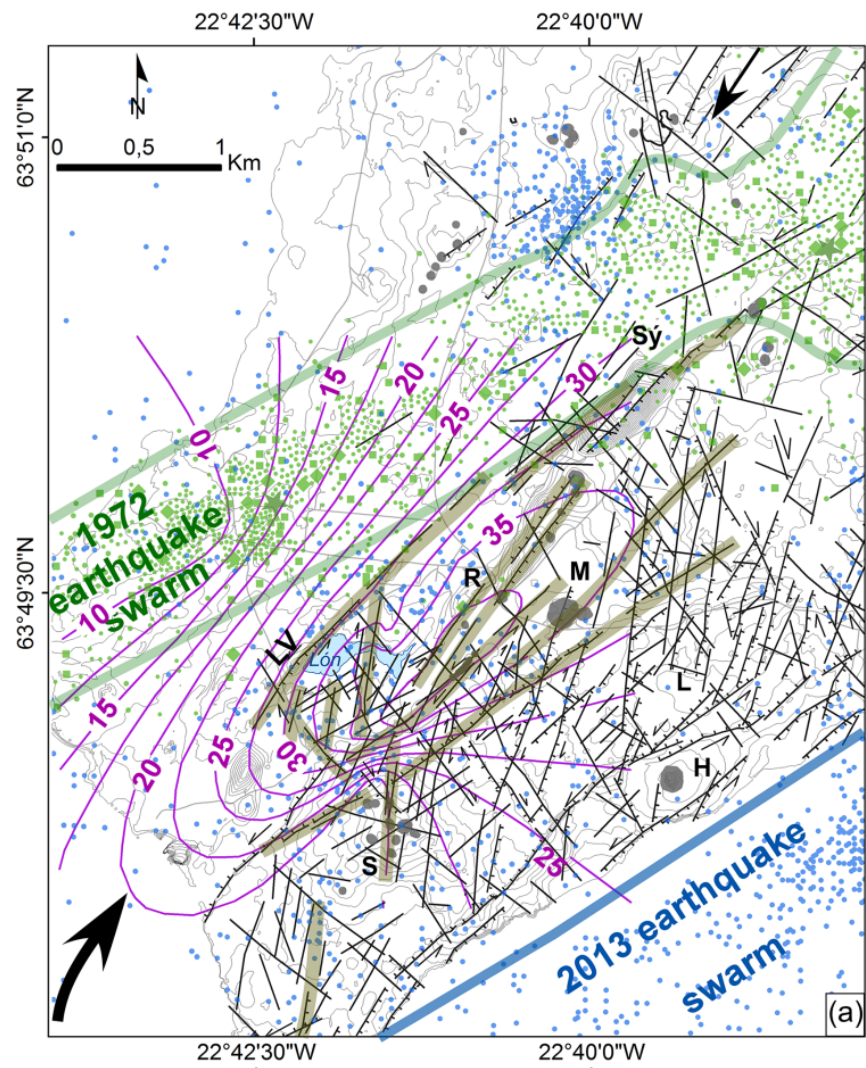

\begin{tabular}{|l} 
Common legend \\
Crater and eruptive \\
fissures
\end{tabular}

Figure 14. Correlation of tectonic pattern with the overall shape of pressure drawdown and subsidence. (a) The pressure drawdown at $1600 \mathrm{~m}$ in bars was calculated for the period of 2008 to 2012 (data, courtesy of Ómar Sigurðsson, HS Orka, 2014). (b) Correlation with the subsidence revealed by InSAR, expressed as $\mathrm{mm} / \mathrm{yr}$. This estimated vertical deformation from TerraSAR-X images covers the period of 2009 to 2013 (after [119]). On both maps, the earthquakes of 1972 (after [107]), 2013-2015 (after [117]), and the structural map (after [65]). 
than the shape of the pressure drawdown, the centre of both is to the east of Lón in the SRSZ. Additionally, their overall shapes fit with the ENE sinistral oblique-slip boundary faults at Litla-Vatnsfell and north of Skálafell. Furthermore, both the maximum drawdown and maximum subsidence occur on the NNE segments of Rauðhólar/Sýrfell (Figure 14(a) and Figure 14(b)).

c) Fluid inclusions [143] [144] and chemical analysis [145] [146] [147] indicate that the geothermal fluid in Reykjanes has a dominant seawater origin although since the Pleistocene meteoric water has also recharged the reservoir. The replacement rate of the reservoir fluid is estimated to range from once every 5 years [148] to once since the last ice age [149]. This natural recharge is considered to occur along two NE-striking rift-parallel structures, which could be vertical semi-permeable boundaries formed by the precipitation of anhydrite [1]. The two boundaries form a NE structure of some $2.5 \mathrm{~km}$ width, stretching from the shore to the latitude of Sýrfell, whose centre coincides with the Rauðhólar/Sýrfell hyaloclastite ridge. Numerical modelling suggests that $2 / 3$ of the natural recharge enters the geothermal system from the southwest quadrant [150].

The structures identified in this study support a dominant recharge of the reservoir fluid from the southwest and show the role of tectonic block compartmentalisation by rift and transform zone structures in the direction of natural recharge. The fluid coming from the northeast encounters the 1972 seismic belt, which acts as a boundary (Figure 14 and Figure 15(a)). Due to this ENE barrier, less fluid enters the reservoir within the SRSZ as a part of it is dissipated through the fracture system within the NRSZ. The fluid coming from the southwest quadrant on the other hand enters the SRSZ within an open area between the 1972 and 2013-2015 seismic belts in a narrow NE corridor. This dominant southwest direction of recharge also fits the shape of pressure drawdown bounded by the ENE sinistral oblique-slip faults of north Skálafell and Litla-Vatnsfell (Figure 14(a) and Figure 15(a)), thus channelling the water from the sea, deep into the reservoir. These are however, regional structural configurations (Figure 15(b)), and different from local barrier and carrier structures within the reservoir (Figures 13(a)-(d)).

\subsection{Structural Control of the Geothermal Reservoir}

All identified fractures playing a role in the geothermal processes were combined and highlighted on the overall structural map (Figure 15(a)). A coherent structural picture emerges, showing the location of the geothermal field compared to the regional tectonic configuration. It is noteworthy that the same sets and even the same fractures control the geothermal processes at surface and depth. These structures are a combination of shear fractures belonging mostly to the transform zone, as well as the rift extensional structures (Figure 15(b)), striking ENE, N-S, NW and NNE. Together they compartmentalise the blocks and act as boundaries and/or pathways to fluid flow. 


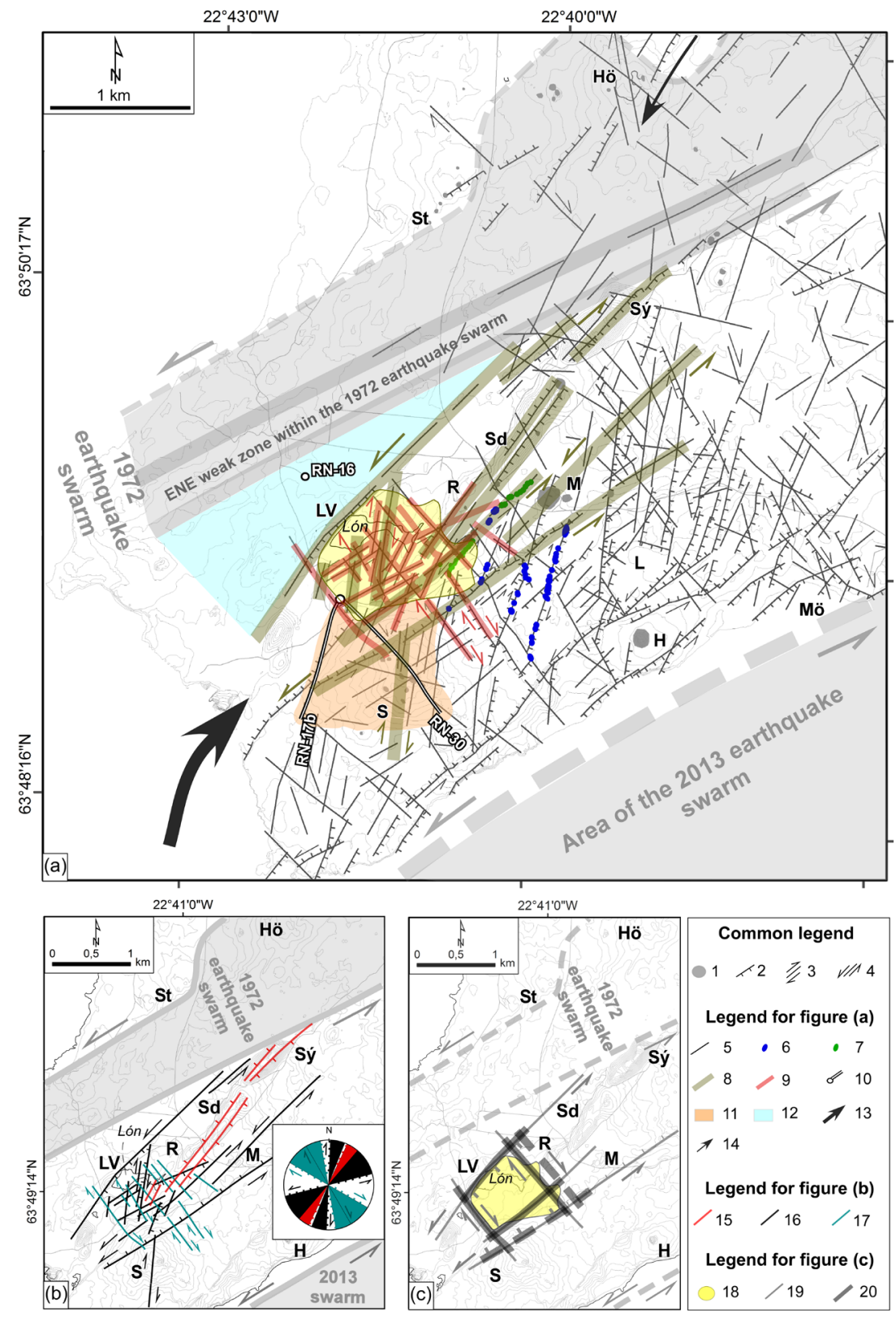

Figure 15. Summary of the structural pattern and the tectonic structures controlling the geothermal processes at surface and depth. (a) Highlights of tectonic fractures controlling the pressure drawdown at $1600 \mathrm{~m}$, the surface geothermal manifestations and the direction of reservoir recharge. (b) Simplified tectonic model of Reykjanes geothermal field and surroundings, reflecting the proportion of extensional and shear fractures. (c) Highlights of the structures controlling the central part of the reservoir. Common legend: (1) Crater and eruptive fissure; (2) Fault with dip-slip (bar towards downthrown block); (3) and (4) Dextral and sinistral strike-slips; (5) Undifferentiated or subtle fracture; (6) Push-ups; (7) Push-ups and sink holes with geothermal steam; (8) Highlight of tectonic structures controlling the isolines of pressure drawdown; (9) Highlight of structures controlling the surface alteration, alignments of fumaroles and mud pools, the $\mathrm{CO}_{2}$ flux, as well as the carrier and barrier fractures to tracer flow at the reservoir level; (10) Selected wells and well paths for discussion; (11) Part of the reservoir with adequate temperature and less permeability based on wells RN-17 and RN-30; (12) Possible colder and least permeable part of the reservoir based on well RN-16; (13) and (14) Respectively, most and least favourable directions of recharge into the reservoir; (15) Extensional rift structure; (16) and (17) Respectively, the Riedel shears of the transform zone and the WNW-NW dextral oblique-slip fractures; (18) Extent of surface alteration, as on figure (a), reflecting the centre of the reservoir with adequate temperature and permeability; (19) and (20) Major ENE sinistral and NW dextral structures, and the highlight of the portion of these faults bounding the geothermal reservoir. 
Regionally, geothermal activity takes place in the western part of the SRSZ between the earthquake swarms of 1972 and 2013 (Figure 15(a)). The structures influencing the pressure drawdown at $1600 \mathrm{~m}$ depth and the related surface subsidence form an elongated deformation band bounded by the ENE sinistral oblique-slip faults of Litla-Vatnsfell, Melur and north of Skálafell. Within this band, series of N-S dextral strike- to oblique-slip faults in the middle of Lón and the NNE extensional structures of Rauðhólar/Sýrfell control the local changes in the shape of the isolines of pressure drawdown. The overall ENE deformation band also explains why the direction of reservoir recharge is more from the southwest (open) than the northeast where the 1972 earthquake swarm acts as a boundary, slowing or dissipating most of the water heading towards the reservoir (Figure 15(a)).

In addition to the abovementioned faults, other ENE sinistral, N-S and NW dextral oblique-slip segments are also open to upflow of hot water and control the distribution of surface alteration and $\mathrm{CO}_{2}$ flux, as well as the alignments of fumaroles, mud pools and steam vents in the reservoir area. These additional structures are dominantly the parallel ENE segments between Litla-Vatnsfell and north of Skálafell, and secondarily a series of NW fractures spread between southwest of Lón and north of Rauðhólar (Figure 9, Figure 12, Figure 15(a)). The distribution of soil temperature, however, is primarily controlled by the NW fault segments between Rauðhólar and Skálafell, and secondarily by the NNE segments of Rauðhólar/Sýrfell and the ENE Litla-Vatnsfell Fault and the push-ups to the east of Rauðhólar. The ENE push-ups are the last structure from which steam escaped the reservoir in 2014 following the earthquakes.

Within the uppermost $2 \mathrm{~km}$ in the reservoir, four of the abovementioned structures play a role as carriers or barriers to the tracer flow: (a) the NNE segments of Rauðhólar/Sýrfell; (b) the WNW/NW segments from Rauðhólar to the east of Skálafell; (c) the ENE segments including the push-ups with steam to the east of Rauðhólar; and (d) the N-S segments crossing Lón (Figure 13 and Figure 15(a)). The fault strikes and particularly the location of the hanging walls compared to the direction of incoming injected water determines whether a structure acts as a carrier or a barrier to the flow.

As to the reservoir boundaries, the extent of the mapped surface alteration indicates that the centre of the reservoir where heat and permeability are the most favourable for production is roughly $1-1.5 \mathrm{~km}^{2}$ (Figure $15(\mathrm{c})$ ), fitting well with the suggested aseismic body under the production field [117]. The centre of the reservoir seems contained between two series of NW dextral oblique-slip faults (Rauðhólar and north of Skálafell), and two sinistral ENE Riedel shears (Litla-Vatnsfell and likely on the trace of the easternmost push-ups with steam). However, this eastern boundary could also be on the trace of the adjacent ENE sinistral oblique-slip fault of Skálafell/Melur (Figure 15(a) and Figure 15(c)) where a structure with similar strike has been known since the 1970's [110] to be present at depth. Well data (ÍSOR database) indicate that either the heat or the permeabil- 
ity are less favourable beyond these structural reservoir boundaries (Figure 15(a)). Results of this study were used to site additional wells in Reykjanes.

\section{Summary and Concluding Remarks}

Selected results of the multidisciplinary structural analysis of the Reykjanes geothermal field and surroundings [65] [67] [114] show the tectonic control of geothermal activity. Extensional and shear fractures in the series $<14.500 \mathrm{yrs}$, along with surface geothermal manifestations, are identified and their tectonic significance interpreted (Figures 1-9). Results are correlated with the 1972 and 2013-2015 earthquakes (Figure 10 and Figure 11), tracer recovery (Figure 13), pressure drawdown and subsidence (Figure 14 and Figure 15). The main conclusions are:

a) The mapped major faults, surface ruptures of earthquakes (push-ups, sink-holes, open fractures), mineral veins, joints, and rare dyke segments form six fractures sets striking N-S $\left(0^{\circ}-27^{\circ} \mathrm{E}\right)$, NNE $\left(\mathrm{N} 28^{\circ}-\mathrm{N} 40^{\circ} \mathrm{E}\right)$, ENE $\left(\mathrm{N} 41^{\circ}-\right.$ $\mathrm{N} 75^{\circ} \mathrm{E}$ ), E-W (on average $\left.\mathrm{N} 90^{\circ} \mathrm{E}\right), \mathrm{WNW}\left(\mathrm{N} 115^{\circ}-\mathrm{N} 130^{\circ} \mathrm{E}\right)$, and $\mathrm{NW} / \mathrm{NNW}$ $\left(\mathrm{N} 140^{\circ}-\mathrm{N} 155^{\circ} \mathrm{E}\right.$ and $\left.\mathrm{N} 165^{\circ} \mathrm{E}\right)$. The ENE set is the most frequent and the E-W the least. All sets have dip-slip ( $<0.5 \mathrm{~m}$ to $\geq 20 \mathrm{~m}$ ), with the higher slips along the ENE, N-S and NE sets. Apertures are $<0.5 \mathrm{~m}$ and rarely $1 \mathrm{~m}$. Both the older faults and the younger surface ruptures display typical left- and right-stepping en échelon arrays, indicating dextral motion along N-S and WNW to NW/NNW fractures and sinistral motion along ENE faults.

b) On RP, the N-S and ENE fractures act as (R') and (R), and the NNE structures also as $(\mathrm{T})$ where $\left(\sigma_{3}\right)$ is estimated at $\mathrm{N} 120^{\circ} \mathrm{E}$ [126] to $\mathrm{N} 133^{\circ} \mathrm{E}$ [16]. Both the fractures and the direction of maximum extension are identical to SISZ [127]. In SISZ, however, the WNW and NW/NNW sets act as sinistral secondary fractures accommodating the sinistral motion of the transform zone, but in Reykjanes the two sets are dextral, widespread, and appear as major fractures. Stress field fluctuations do not explain the origin of the WNW and NW/NNW sets, but the sets could have been formed during older plate re-organisation in nearby onshore and offshore regions. Kinematically, however, the two sets could also be explained as horsetail splay structures.

c) The structural weak zones of the six sets group into two adjacent ENE sinistral Riedel shear zones (NRSZ and SRSZ). The 1972 seismic belt separates these zones and the 2013 earthquake swarm forms the southern boundary of the SRSZ. The NRSZ and SRSZ indicate that the transform zone could be at least 7.5 $\mathrm{km}$ wide (wider than previously thought). The SRSZ is more heavily fractured and is the loci of the 2013-2015 earthquakes, indicating that this is presently the most active part of the transform zone.

d) The bend of the Rauðhólar/Sýrfell segments and the Litla-Vatnsfell Fault from NNE to ENE within the SRSZ occurs as these structures approach the 1972 seismic belt. This clockwise rotation is compatible with the sinistral motion of the ENE boundary between the two Riedel shear zones. Compression induced by 
this clockwise rotation is expressed in the few reverse-slip FPS of the 2013-2015 earthquakes and the dominance of compressional push-ups on the eastern block of this rotated structure. Reverse-slip motions in Iceland result from local bend of steeply-dipping normal faults or in association with dyke injections [138], as well as block rotation [139].

e) The right-stepping geometry of the eruptive fissure at Klofningar (Eldvörp) and the 1972 FPS indicate magma injection into oblique-slip sinistral strike-slip faults, which is known from other parts of Iceland [62] [86] [128]. Furthermore, the cluster of the 1972 earthquakes that shoots off the ENE trending seismic belt into the NNE Haugur Graben indicates that during episodes of transform faulting, related earthquakes can "leak" into rift structures, reactivating them.

f) Seismic lineations of the 1972 and 2013-2015 earthquakes align on many of the mapped fractures of the six sets. Three structures are particularly critical for the distribution and of the FPS. The 1972 earthquakes occurred within the NRSZ with mixed normal-slip and strike-slip fault ruptures. The FPS of the 2013-2015 earthquakes in the NRSZ are normal-slip, but in the SRSZ the FPS are strike-slip to the east of the NNE segments of Rauðhólar/Sýrfell and mixed dip-slip to the west of it.

g) A WNW seismic lineation of the 1972 earthquakes could extend into the SRSZ, bounding a more heavily fractured block to the west where the geothermal field is located. The extent of surface alteration indicates that the centre of the reservoir with adequate temperature and permeability is about $1-1.5 \mathrm{~km}^{2}$, coinciding with the aseismic body under the production field [117], and bounded by two WNW dextral strike-slip faults at Rauðhólar and north of Skálafell, and by the ENE sinistral oblique-slip faults of Litla-Vatnsfell and north of Skálafell. The ENE, N-S, NW and NNE fractures control the overall shape of pressure drawdown at $1600 \mathrm{~m}$ depth and the surface subsidence due to production. The same fractures also control the distribution of surface temperature, alteration, fumaroles, mud pools, and $\mathrm{CO}_{2}$ flux, acting also as carriers or barriers to tracer flow paths.

Oblique rifts are more commonly investigated in terms of deformation of the rift segments. Results of this study provide insights into the range of deformation in a highly oblique rift in the presence of a transform segment. Results demonstrate that at a young stage of development (Holocene), shear fractures are more common, controlling the seismo-tectonic deformation, magmatism and geothermal activity at surface and depth. A key structural feature is block compartmentalisation at any scale and given location. Not only does the compartmentalisation play a critical role in rupture of the weakest structural zones during earthquakes, but it also sheds light on the boundaries beyond which fault types or fault density may change, both with implications on fluid flow and fracture permeability.

\section{Acknowledgements}

The task of original data analysis and writing of the report "The 2016 conceptual 
model of Reykjanes" was funded by the European Union Horizon 2020 Research and Innovation Programme (grant agreement No. 690771). The authors thank HS Orka and in particular Pór Gíslason for permission to publish the results of the multidisciplinary structural analysis of Reykjanes in this paper. Additional support for this publication was received from the Energy Research Fund of Landsvirkjun (National Power Company of Iceland). The assistance of Joanna Cheng, the Managing editor, and the constructive remarks of anonymous reviewers improved this paper.

\section{References}

[1] Porbjörnsson, D., Halldórsdóttir, S., Franzson, H., Karlsdóttir, R., Friðriksson, P., Níelsson, S., Einarsson, G.M.E. and Óskarsson, F. (2014) Reykjanes-Conceptual Model Updated to March 2014. Iceland GeoSurvey, Report, ÍSOR 2014/049, 62 p.

[2] Weisenberger, T.B., Harðarson, B.S., Kästner, F., Gunnarsdóttir, S.H., Tulinius, H., Guðmundsdóttir, V., Einarsson, G.M., Pétursson, F., Vilhjálmsson, S., Stefánsson, H.Ö. and Níelsson, S. (2017) Well Report-RN-15/IDDP-2. Drilling in Reykjanes-Phases 4 and 5 from 3000 to $4659 \mathrm{~m}$. Iceland GeoSurvey, Report ÍSOR-2017/016, $228 \mathrm{p}$.

[3] Barberi, F., Marinelli, G., Santacroce, R., Tazieff, H., Varet, J., Chedeville, E., Faure, H. and Giglia, G. (1973) Geology of Northern Afar (Ethiopia). Revue de Géographie Physique et de GéologieDynamique, Paris, 15, 443-490.

[4] Cole, J.W. (1990) Structural Control and Origin of Volcanism in the Taupo Volcanic Zone, New Zealand. Bulletin of Volcanology, 52, 445-459. https://doi.org/10.1007/BF00268925

[5] Feng, Q. and Lees, J.M. (1998) Microseismicity, Stress, and Fracture in the Coso Geothermal Field, California. Tectonophysics, 289, 221-238.

https://doi.org/10.1016/S0040-1951(97)00317-X

[6] Corti, G. (2009) Continental Rift Evolution: From Rift Initiation to Incipient Break-Up in the Main Ethiopian Rift, East Africa. Earth Science Reviews, 96, 1-53. https://doi.org/10.1016/j.earscirev.2009.06.005

[7] Lamarche, G., Barnes, P.M. and Bull, J.M. (2006) Faulting and Extension Rate over the Last 20,000 Years in the Offshore Whakatane Graben, New Zealand Continental Shelf. Tectonics, 25, TC4005. https://doi.org/10.1029/2005TC001886

[8] Hauksson, E. and Unruh, J. (2007) Regional Tectonics of the Coso Geothermal Area along the Intracontinental Plate Boundary in Central Eastern California: Three-Dimensional Vp and Vp/Vs Models, Spatial-Temporal Seismicity Patterns, and Seismogenic Deformation. Journal of Geophysical Research, 112, B06309. https://doi.org/10.1029/2006JB004721

[9] Davatzes, N.C. and Hickman, S.H. (2010) The Feedback between Stress, Faulting, and Fluid Flow: Lessons from the Coso Geothermal Field, CA, USA. Proceedings World Geothermal Congress, Bali, 25-29 April 2010.

[10] Curewitz, D. and Karson, J.A. (1997) Structural Settings of Hydrothermal Outflow: Fracture Permeability Maintained by Fault Propagation and Interaction. Journal of Volcanology and Geothermal Research, 79, 149-168. https://doi.org/10.1016/S0377-0273(97)00027-9

[11] Acocella, V., Korme, T., Salvini, F. and Funiciello, R. (2002) Elliptic Calderas in the Ethiopian Rift: Control of Pre-Existing Structures. Journal of Volcanology and Geothermal Research, 119, 189-203. 
https://doi.org/10.1016/S0377-0273(02)00342-6

[12] Meixner, J., Schill, E., Grimmer, J.C., Gaucher, E., Kohl, T. and Klingler, Ph. (2016) Structural Control of Geothermal Reservoirs in Extensional Tectonic Settings: An Example from the Upper Rhine Graben. Journal of Structural Geology, 82, 1-15. https://doi.org/10.1016/j.jsg.2015.11.003

[13] Pérez-Flores, P., Veloso, E., Cembrano, J., Sánchez-Alfaro, P., Lizama, M. and Arancibia, G. (2017) Fracture Network, Fluid Pathways and Paleostress at the Tolhuaca Geothermal Field. Journal of Structural Geology, 96, 134-148. https://doi.org/10.1016/j.jsg.2017.01.009

[14] Einarsson, P. (1991) Earthquakes and Present-Day Tectonism in Iceland. Tectonophysics, 189, 261-279. https://doi.org/10.1016/0040-1951(91)90501-I

[15] Hreinsdóttir, S. and Einarsson, P. (2001) Crustal Deformation at the Oblique Spreading Reykjanes Peninsula, SW Iceland: GPS Measurements from 1993 to 1998. Journal of Geophysical Research, 106, 13803-13816. https://doi.org/10.1029/2001JB000428

[16] Clifton, A.E. and Schlische, R.W. (2003) Fracture Populations on the Reykjanes Peninsula, Iceland: Comparison with Experimental Clay Models of Oblique Rifting. Journal of Geophysical Research, 108, B2, 2074.

[17] Ewing, M. and Heezen, B.C. (1960) Continuity of Mid-Oceanic Ridge and Rift Valley in the Southwestern Indian Ocean Confirmed. Science, 131, 1677-1679. https://doi.org/10.1126/science.131.3414.1677

[18] Vine, F.J. (1966) Spreading of the Ocean Floor; New Evidence. Science, 154, 1405-1415. https://doi.org/10.1126/science.154.3755.1405

[19] Matthews, D.H., Williams, C. and Laughton, A.S. (1967) Mid-Ocean Ridge in the Mouth of the Gulf of Aden. Nature, 215, 1052-1053. https://doi.org/10.1038/2151052a0

[20] Laughton, A.S., Whitmarsh, R.B. and Jones M.T. (1970) The Evolution of the Gulf of Aden. Philosophical Transactions of the Royal Society of London, A267, 227-266.

[21] Talwani, M. and Eldholm, O. (1977) Evolution of the Norwegian-Greenland Sea. Geological Society of America Bulletin, 88, 969-999. https://doi.org/10.1130/0016-7606(1977)88<969:EOTNS>2.0.CO;2

[22] Vogt, P.R., Taylor, P.T., Kovacs, L.C. and Johnson, G.L. (1979) Detailed Aeromagnetic Investigation of the Arctic Basin. Journal of Geophysical Research, 84, 1071-1089. https://doi.org/10.1029/JB084iB03p01071

[23] Atwater, T. (1981) Propagating Rifts in Sea Floor Spreading Patterns. Nature, 290, 185-186. https://doi.org/10.1038/290185a0

[24] Dauteuil, P. and Brun, J.P. (1996) Deformation Partitioning in a Slow-Spreading Ridge Undergoing Oblique Extension (Mohns Ridge-Norwegian Sea). Tectonics, 15, 870-884. https://doi.org/10.1029/95TC03682

[25] Dauteuil, P., Huchon, P., Quemeneur, F. and Souriot, T. (2001) Propagation of an Oblique Spreading Centre: The Western Gulf of Aden. Tectonophysics, 332, 423-442. https://doi.org/10.1016/S0040-1951(00)00295-X

[26] Sanderson, D.J. and Marchini, W.R.D. (1984) Transpression. Journal of Structural Geology, 6, 449-458. https://doi.org/10.1016/0191-8141(84)90058-0

[27] Fossen, H. and Tikoff, B. (1998) Extended Models of Transpression and Transtension, and Application to Tectonic Settings. In: Holdsworth, R.E., Strachan, R.A. and Dewey, J.F., Eds., Continental Transpressional and Transtensional Tectonics. Geological Society of London, Special Publications, 135, 1-14. 
[28] Withjack, M.O. and Jamison, W.R. (1986) Deformation Produced by Oblique Rifting. Tectonophysics, 126, 99-124. https://doi.org/10.1016/0040-1951(86)90222-2

[29] Garfunkel, Z. (1981) Internal Structure of the Dead Sea Leaky Transform (Rift) in Relation to Plate Kinematics. Tectonophysics, 80, 81-108.

https://doi.org/10.1016/0040-1951(81)90143-8

[30] Ben-Avraham, Z. and Zoback, M.D. (1992) Transform-Normal Extension and Asymmetric Basins: An Alternative to Pull-Apart Models. Geology, 20, 423-426. https://doi.org/10.1130/0091-7613(1992)020<0423:TNEAAB>2.3.CO;2

[31] Morley, C.K., Nelson, R.A., Patton, T.L. and Munn, S.G. (1990) Transfer Zones in the East African Rift System and Their Relevance to Hydrocarbon Exploration in Rifts. American Association of Petroleum Geologists Bulletin, 74, 1234-1253.

[32] Nelson, R.A., Patton, T.L. and Morley, C.K. (1992) Rift-Segment Interaction and Its Relation to Hydrocarbon Exploration in Continental Rift Systems. American Association of Petroleum Geologists Bulletin, 76, 1153-1169.

[33] Wheeler, W.H. and Karson, J.A. (1994) Extension and Subsidence Adjacent to a "Weak" Continental Transform: An Example from the Rukwa Rift, East Africa. Geology, 22, 625-628. https://doi.org/10.1130/0091-7613(1994)022<0625:EASATA >2.3.CO;2

[34] Thomas, W.A. (2006) Tectonic Inheritance at a Continental Margin. Geological Society of America Today, 16, 4-11. https://doi.org/10.1130/1052-5173(2006)016[4:TIAACM]2.0.CO;2

[35] Corti, G. (2012) Evolution and Characteristics of Continental Rifting: Analog Modeling Inspired View and Comparison with Examples from the East African Rift System. Tectonophysics, 522-523, 1-33. http://dx.doi.org/10.1016/j.tecto.2011.06.010

[36] Bellahsen, N., Leroy, S., Autin, J., Razin, P., d'Acremont, E., Sloan, H., Pik, R., Ahmed, A. and Khanbari, K. (2013) Pre-Existing Oblique Transfer Zones and Transfer/Transform Relationships in Continental Margins: New Insights from the Southeastern Gulf of Aden, Socotra Island, Yemen. Tectonophysics, 607, 32-50. https://doi.org/10.1016/j.tecto.2013.07.036

[37] Audet, P. and Bürgmann, R. (2011) Dominant Role of Tectonic Inheritance in Supercontinent Cycles. Nature Geoscience, 4, 184-187. https://doi.org/10.1038/ngeo1080

[38] Tesauro, M., Kaban, M.K. and Cloetingh, S. (2012) Global Strength and Elastic Thickness of the Lithosphere. Global and Planetary Change, 90-91, 51-57. https://doi.org/10.1016/j.gloplacha.2011.12.003

[39] Ziegler, P.A. and Cloetingh, S. (2004) Dynamic Processes Controlling Evolution of Rifted Basins. Earth Science Review, 64, 1-50. https://doi.org/10.1016/S0012-8252(03)00041-2

[40] Philippon, M. and Corti, G. (2016) Obliquity along Plate Boundaries. Tectonophysics, 693, 171-182. https://doi.org/10.1016/j.tecto.2016.05.033

[41] Aydin, A. and Nur, A. (1985) The Types and Role of Stepovers in Strike Slip Tectonics. In: Biddle, K.T. and Christie-Blick, N., Eds., Strike-Slip Deformation, Basin Formation, and Sedimentation. Society of Economic Paleontologists and Mineralogists, Special Publication, 37, 35-44.

[42] Harding, T.P., Vierbuchen, R.C. and Christie-Blick, N. (1985) Structural Styles, Plate-Tectonic Settings, and Hydrocarbon Traps of Divergent (Transtensional) Wrench Faults. In: Biddle, K.T. and Christie-Blick, N., Eds., Strike-Slip Deformation, Basin Formation, and Sedimentation. Society of Economic Paleontologists and 
Mineralogists, special publication, 37, 51-77.

[43] Tron, V. and Brun, J.P. (1991) Experiments on Oblique Rifting in Brittle-Ductile Systems. Tectonophysics, 188, 71-84. https://doi.org/10.1016/0040-1951(91)90315-J

[44] McClay, K.R. and White, M.J. (1995) Analogue Modelling of Orthogonal and Oblique Rifting. Marine and Petroleum Geology, 12, 137-151. https://doi.org/10.1016/0264-8172(95)92835-K

[45] Bonini, M., Souriot, T., Boccaletti, M. and Brun, J.P. (1997) Successive Orthogonal and Oblique Extension Episodes in a Rift Zone: Laboratory Experiments with Application to the Ethiopian Rift. Tectonics, 16, 347-362. https://doi.org/10.1029/96TC03935

[46] Clifton, A.E., Schlische, R.W., Withjack, M.O. and Ackermann, R.V. (2000) Influence of Rift Obliquity on Fault-Population Systematics: Results of Experimental Clay Models. Journal of Structural Geology, 22, 1491-1509. https://doi.org/10.1016/S0191-8141(00)00043-2

[47] Mart, Y. and Dauteuil, O. (2000) Analogue Experiments of Propagation of Oblique Rifts. Tectonophysics, 316, 121-132. https://doi.org/10.1016/S0040-1951(99)00231-0

[48] Agostini, A., Bonini, M., Corti, G., Sani, F. and Mazzarini, F. (2011) Fault Architecture in the Main Ethiopian Rift and Comparison with Experimental Models: Implications for Rift Evolution and Nubia-Somalia Kinematics. Earth and Planetary Science Letters, 301, 479-492. https://doi.org/10.1016/j.epsl.2010.11.024

[49] Hayward, N.J. and Ebinger, C.J. (1996) Variations in the Along-Axis Segmentation of the Afar Rift System. Tectonics, 15, 244-257. https://doi.org/10.1029/95TC02292

[50] Bonini, M., Corti, G., Innocenti, F., Manetti, P., Mazzarini, F., Abebe, T. and Pecskay, Z. (2005) Evolution of the Main Ethiopian Rift in the Frame of Afar and Kenya Rifts Propagation. Tectonics, 24, TC1007. https://doi.org/10.1029/2004TC001680

[51] Laughton, A.S. (1966) The Gulf of Aden. Philosophical Transactions of the Royal Society of London, A259, 150-171.

[52] Atwater, T. and Macdonald, K.C. (1977) Are Spreading Centres Perpendicular to Their Transform Faults? Nature, 270, 715-719. https://doi.org/10.1038/270715a0

[53] Abelson, M. and Agnon, A. (1997) Mechanics of Oblique Spreading and Ridge Segmentation. Earth and Planetary Science Letters, 148, 405-421. https://doi.org/10.1016/S0012-821X(97)00054-X

[54] Taylor, B., Goodliffe, A. and Martinez, F. (2009) Initiation of Transform Faults at Rifted Continental Margins. Comptes Rendus Geoscience, 341, 428-438. https://doi.org/10.1016/j.crte.2008.08.010

[55] Agostini, A., Corti, G., Zeoli, A. and Mulegeta, G. (2009) Evolution, Pattern and Partitioning of Deformation during Oblique Continental Rifting: Inferences from Lithospheric Scale Centrifuge Models. AGU Geochemistry, Geophysics, Geosystems, 10, Q11015. https://doi.org/10.1029/2009GC002676

[56] Jóhannesson, H. and Sæmundsson, K. (1998) Geological Map of Iceland, Tectonics, scale 1:500.000. Icelandic Institute of Natural History, Reykjavík.

[57] Huchon, P. and Khanbari, K. (2003) Rotation of the Syn-Rift Stress Field of the Northern Gulf of Aden Margin, Yemen. Tectonophysics, 364, 147-166. https://doi.org/10.1016/S0040-1951(03)00056-8

[58] Fournier, M., Bellahsen, N., Fabbri, O. and Gunnell, Y. (2004) Oblique Rifting and Segmentation of the NE Gulf of Aden Passive Margin. AGU Geochemistry, Geo- 
physics, Geosystems, 5, Q11005. https://doi.org/10.1029/2004GC000731

[59] Brune, S. and Autin, J. (2013) The Rift to Break-Up Evolution of the Gulf of Aden: Insights from 3D Numerical Lithospheric-Scale Modelling. Tectonophysics, 607, 65-79. https://doi.org/10.1016/j.tecto.2013.06.029

[60] Talwani, M., Windisch, C.C. and Langseth, M.G. (1971) Reykjanes Ridge Crest: A Detailed Geophysical Study. Journal of Geophysical Research, 76, 473-516. https://doi.org/10.1029/JB076i002p00473

[61] Palgan, D., Devey, C.W. and Yeo, I.A. (2017) Volcanism and Hydrothermalism on a Hotspot-Influenced Ridge: Comparing Reykjanes Peninsula and Reykjanes Ridge, Iceland. Journal of Volcanology and Geothermal Research, 348, 62-81. https://doi.org/10.1016/j.jvolgeores.2017.10.017

[62] Brandsdóttir, B., Riedel, C., Richter, B., Helgadóttir, G., Kjartansson, E., Detrick, R., Dahm, T., Mayer, L., Calder, B. and Driscoll, N. (2005) Multibeam Bathymetric Maps of the Kolbeinsey Ridge and Tjörnes Fracture Zone, N-Iceland. EGU General Assembly, Nice, France.

[63] Clifton, A.E. and Kattenhorn, S.A. (2006) Structural Architecture of a Highly Oblique Divergent Plate Boundary Segment. Tectonophysics, 419, 27-40. https://doi.org/10.1016/j.tecto.2006.03.016

[64] DeMets, C., Gordon, R.G. and Argus, D.F. (2010) Geologically Current Plate Motions. Geophysical Journal International, 181, 1-80. https://doi.org/10.1111/j.1365-246X.2009.04491.x

[65] Khodayar, M., Björnsson, S., Níelsson, S., Axelsson, G. and Franzson, H. (2014a) Preliminary Structural Analysis of Reykjanes for Re-Injection. Iceland GeoSurvey, Report ÍSOR-2014/039, 96 p., 1 Map. Prepared for HS Orka/Alterra Power.

[66] Khodayar, M., Björnsson, S., Axelsson, G., Nielsson, S., Franzson, H. and Karlsdóttir, R. (2014b) Structural Targets for Re-Injection Well RN-34 in Reykjanes, SW Iceland. Short Report Iceland GeoSurvey ÍSOR-14064, 20 p.

[67] Khodayar, M., Níelsson, S., Björnsson, S. and Guðnason, E.Á. (2017) Structural Targets and Drilling Choices for Well RN-35 Based on Selected Data, Reykjanes, Southwest Iceland. Iceland GeoSurvey Report, ÍSOR-2017/007, 32 p.

[68] Wolfe, C.J., Bjarnason, I.Th., VanDecar, J.C. and Solomon, S.C. (1997) Seismic Structure of the Iceland Mantle Plume. Nature, 385, 245-257. https://doi.org/10.1038/385245a0

[69] Bjarnason, I.Th. (2008) An Iceland Hotspot Saga. Jökull, 58, 3-16.

[70] White, R.S. and Mckenzie, D. (1989) Magmatism at Rift Zones: The Generation of Volcanic Continental Margins and Flood Basalts. Journal of Geophysical Research, 94, 7685-7729. https://doi.org/10.1029/JB094iB06p07685

[71] Saunders, A.D., Fitton, J.G., Kerr, A.C., Norry, M.J. and Kent, R.W. (1997) The North Atlantic Igneous Province. In: Mahoney, J.J. and Coffin, M.L., Eds., Large Igneous Provinces: Washington, D.C., American Geophysical Union Geophysical Monograph, 100, 45-93. https://doi.org/10.1029/GM100p0045

[72] Walker G.P.L. (1960) Zeolite Zones and Dike Distribution in Relation to the Structure of the Basalts of Eastern Iceland. Journal of Geology, 68, 515-528. https://doi.org/10.1086/626685

[73] McDougall, I., Saemundsson, K., Jóhannesson, H., Watkins, N.D. and Kristjánsson, L. (1977) Extension of the Geomagnetic Time Scale to 6.5 m.y.: K-Ar Dating, Geological and Paleomagnetic Study of a 3,500 m Lava Succession in Western Iceland. Bulletin of Geological Society of America, 88, 1-15. 
https://doi.org/10.1130/0016-7606(1977)88<1:EOTGPT>2.0.CO;2

[74] Harðarson, B.S., Fitton, J.G., Ellam, R.M. and Pringle, M.S. (1997) Rift Relocation-A Geochemical and Geochronological Investigation of a Palaeo-Rift in Northwest Iceland. Earth and Planetary Science Letters, 153, 181-196. https://doi.org/10.1016/S0012-821X(97)00145-3

[75] Einarsson, P., Klein, F.W. and Björnsson, S. (1977) The Borgarfjörður Earthquakes in West Iceland 1974. Seismological Society of America Bulletin, 67, 187-208.

[76] Sigurðsson, H. (1970) Structural Origin and Plate Tectonics of the Snæfellsnes Volcanic Zone, Western Iceland. Earth and Planetary Science Letters, 10, 129-135. https://doi.org/10.1016/0012-821X(70)90074-9

[77] Jakobsson, S.P. (1972) Chemistry and Distribution Pattern of Recent Basaltic Rocks in Iceland. Lithos, 5, 365-386. https://doi.org/10.1016/0024-4937(72)90090-4

[78] Tryggvason, E. (1959) Earthquakes in Iceland during the Years 1956, 1957, 1958. Náttúrufræðingurinn, 29, 84-91. (In Icelandic)

[79] Sykes, L.R. (1967) Mechanism of Earthquakes and Nature of Faulting on the Mid-Oceanic Ridges. Journal of Geophysical Research, 72, 2131-2153. https://doi.org/10.1029/JZ072i008p02131

[80] Ward, P.L. (1971) New Interpretation of the Geology of Iceland. Geological Society of America Bulletin, 82, 2991-3012. https://doi.org/10.1130/0016-7606(1971)82[2991:NIOTGO]2.0.CO;2

[81] Jakobsdóttir, S.S. (2008) Seismicity in Iceland: 1994-2007. Jökull, 58, 75-100.

[82] Sæmundsson, K. (1979) Outline of Geology of Iceland. Jökull, 29, 7-28.

[83] Jóhannesson, H. (1980) Evolution of the Rift Zones in Western Iceland. Náttúrufræðingurinn, 50, 13-31. (In Icelandic with English Summary)

[84] Helgason, J. (1984) Frequent Shifts of the Volcanic Zone in Iceland. Geology, 12, 212-216. https://doi.org/10.1130/0091-7613(1984)12<212:FSOTVZ>2.0.CO;2

[85] Schäfer, K. (1972) Transform Faults in Iceland. Geologische Rundschau, 61, 942-960. https://doi.org/10.1007/BF01820899

[86] Khodayar, M. and Einarsson, P. (2002) Strike-Slip Faulting, Normal Faulting, and Lateral Dike Injections along a Single Fault: Field Example of the Gljúfurá Fault near a Tertiary Oblique Rift-Transform Zone, Borgarfjörður, West Iceland. Journal of Geophysical Research, 107. https://doi.org/10.1029/2001JB000150

[87] Bodvarsson, G. and Walker, G.P.L. (1964) Crustal Drift in Iceland. The Geophysical Journal of the Royal Astronomical Society, 8, 285-300. https://doi.org/10.1111/j.1365-246X.1964.tb06295.x

[88] Sæmundsson, K. (1978) Fissure Swarms and central Volcanoes of the Neovolcanic Zones of Iceland. In: Crustal Evolution in Northwestern Britain and Adjacent Regions. Geological Journal, Special Issue, 10, 415-432.

[89] Arnórsson, S., Axelsson, G. and Sæmundsson, K. (2008) Geothermal Systems in Iceland. Jökull, 51, 269-302.

[90] Björnsson, A., Johnsen, G., Sigurðsson, S., Thorbergsson, G. and Tryggvason, E. (1979) Rifting of the Plate Boundary in North Iceland 1975-1978. Journal of Geophysical Research, 84, 3029-3038. https://doi.org/10.1029/JB084iB06p03029

[91] Sigmundsson, F., Hooper, A., Hreinsdottir, S:, Vogfjörð, K.S., Ófeigsson, B.G., Heimisson, E.R., Dumont, S., Parks, M., Spaans, K., Gudmundsson, G.B., Drouin, V., Arnadottir, T., Jonsdottir, K., Gudmundsson, M.T., Hognadottir, T., Fridriksdottir, H.M., Hensch, M., Einarsson, P., Magnusson, E., Samsonov, S., Brandsdottir, 
B., White, R.S., Agustsdottir, T., Greenfield, T., Green, R.G., Hjartardottir, A.R., Pedersen, R., Bennett, R.A., Geirsson, H., La Femina, P.C., Bjornsson, H., Palsson, F., Sturkell, E., Bean, C.J., Mollhoff, M., Braiden, A.K. and Eibl, E.P.S. (2015) Segmented Lateral Dyke Growth in a Rifting Event at Bardarbunga Volcanic System, Iceland. Nature, 517, 191-195. https://doi.org/10.1038/nature14111

[92] Rögnvaldsson, S., Guðmundsson, A. and Slunga, R. (1998) Seismotectonic Analysis of the Tjörnes Fracture Zone, an Active Transform Fault in North Iceland. Journal of Geophysical Research, 103, 30117-30129. https://doi.org/10.1029/98JB02789

[93] Stefánsson, R., Guðmundsson, G.B. and Halldórsson, P. (2008) Tjörnes Fracture Zone. New and Old Seismic Evidences for the Link between the North Iceland Rift Zone and the Mid-Atlantic Ridge. Tectonophysics, 447, 117-126. https://doi.org/10.1016/j.tecto.2006.09.019

[94] Einarsson, P. (2008) Plate Boundaries, Rifts and Transforms in Iceland. Jökull, 58, 35-58.

[95] Decriem, J., Árnadóttir, T., Hooper, A., Geirsson, H., Sigmundsson, F., Keiding, M., Ófeigsson, B.G., Hreinsdóttir, S., Einarsson, P., LaFemina, P. and Bennett, R.A. (2010) The 2008 May 29 Earthquake Doublet in SW Iceland. Geophysical Journal International, 181, 1128-1146. https://doi.org/10.1111/j.1365-246X.2010.04565.x

[96] Khodayar, M. and Björnsson, S. (2014) Fault Ruptures and Geothermal Effects of the Second Earthquake, 29 May 2008, South Iceland Seismic Zone. Geothermics, 50, 44-65. http://dx.doi.org/10.1016/j.geothermics.2013.07.002

[97] Sigmundsson F., Einarsson, P., Bilham, R. and Sturkell, E. (1995) Rift-Transform Kinematics in South Iceland: Deformation from Global Positioning System Measurements, 1986 to 1992. Journal of Geophysical Research, 100, 6235-6248. https://doi.org/10.1029/95JB00155

[98] La Femina, P.C., Dixon, T.H., Malservisi, R., Árnadóttir, Th., Sturkell, E., Sigmundsson, F. and Einarsson, P. (2005) Geodetic GPS Measurements in South Iceland: Strain Accumulation and Partitioning in a Propagating Ridge System. Journal of Geophysical Research, 110, B11405.

[99] Parson, L.M., Murton, B.J., Searle, R.C., Booth, D., Evans, J., Field, P., Keeton, J., Laughton, A., McAllister, E., Millard, N., Redbourne, L., Rouse, I., Shor, I., Smith, D., Spencer, S., Summerhayes, C. and Walker, C. (1993) En Echelon Axial Volcanic Ridges at Reykjanes Ridge: A Life Cycle of Volcanism and Tectonics. Earth and Planetary Science Letters, 117, 73-87. https://doi.org/10.1016/0012-821X(93)90118-S

[100] Vogt, P.R. (1971) Astenosphere Motion Recorded by the Ocean Floor South of Iceland. Earth and Planetary Science Letters, 13, 153-160. https://doi.org/10.1016/0012-821X(71)90118-X

[101] Hey, R., Martinez, F., Höskuldsson, Á. and Benediktsdóttir, Á. (2010) Propagating Rift Model for the V-Shaped Ridges South of Iceland. AGU Geochemistry, Geophysics, Geosystems, 11, Q03011. https://doi.org/10.1029/2009GC002865

[102] Trippanera, D., Acocella, V., Ruch, J. and Abebe, B. (2015) Fault and Graben Growth along Active Magmatic Divergent Plate Boundaries in Iceland and Ethiopia. Tectonics, 34, 2318-2348. https://doi.org/10.1002/2015TC003991

[103] Sæmundsson, K. and Einarsson, P. (2014) Notes on the Tectonics of Reykjanes. Iceland GeoSurvey, Report ÍSOR-2014/003, 28 p.

[104] Keiding, M., Árnadóttir, Th., Jónsson, S., Decriem, J. and Hooper, A. (2010) Plate Boundary Deformation and Man-Made Subsidence around Geothermal Fields on the Reykjanes Peninsula, Southwest Iceland. Journal of Volcanology and Geother- 
mal Research, 194, 139-149. https://doi.org/10.1016/j.jvolgeores.2010.04.011

[105] Sigurðsson, F. (1985) Groundwater and Hydrogeology on the Outer Reykjanes Peninsula, III. Appendix on Tectonics. National Energy Authority of Iceland Report, OS-85075/VOD-06, 43 p. (In Icelandic)

[106] Sæmundsson, K., Sigurgeirsson, M.Á., Hjartarson, Á., Kaldal, I., Kristinsson, S.G. and Víkingsson, S. (2016) Geological Map of Southwest Iceland, 1:100.000. Second edition, Reykjavík, Iceland GeoSurvey (ÍSOR).

[107] Klein F.W., Einarsson, P. and Wyss, M. (1977) The Reykjanes Peninsula, Iceland, Earthquake Swarm of September 1972 and Its Tectonic Significance. Journal of Geophysical Research, 82, 856-888. https://doi.org/10.1029/JB082i005p00865

[108] Steinthórsson, S., Óskarsson, N., Arnórsson, S. and Gunnlaugsson, E. (1986) Metosomatism in Iceland: Hydrothermal Alteration and Remelting of Oceanic Crust. NATO ASI Chemical Transport to Metasomatic Processes, Attica, 3-16 June 1986, 355-387.

[109] Ármannsson, H. (2016) The Fluid Geochemistry of Icelandic High Temperature Geothermal Areas. Applied Geochemistry, 66, 16-64. https://doi.org/10.1016/j.apgeochem.2015.10.008

[110] Björnsson, S., Arnórsson, S. and Tómasson, J. (1972) Economic Evaluation of Reykjanes Thermal Brine Area, Iceland. American Association of Petroleum Geologists Bulletin, 56, 2380-2391.

[111] Franzson, H. (2004) The Reykjanes High-Temperature Geothermal System. Geological and Geothermal Model. Iceland GeoSurvey, Report, ÍSOR-2004/012, 60 p. (In Icelandic)

[112] Friðleifsson, G.Ó. and Richter, B. (2010) The Geological Significance of Two IDDP-ICDP Spot Cores from the Reykjanes Geothermal Field, Iceland. Proceedings World Geothermal Congress, Bali, April 2010, 7 p.

[113] Weisenberger, T.B., Einarsson, G.M., Harðarson, B.S. and Níelsson, S. (2016) Lithostratigraphic Model of the Reykjanes Geothermal Field. Iceland GeoSurvey, Short Report, ÍSOR-16076, $11 \mathrm{p}$.

[114] Khodayar, M., Níelsson, S., Hickson, C., Guðnason, E.Á., Harðarson, B.S., Guðmundsdóttir, V., Halldórsdóttir, S., Óskarsson, F., Weisenberger, T.B. and Björnsson, S. (2016) The 2016 Conceptual Model of Reykjanes Geothermal System, SW Iceland. Prepared for DEEPEGS Geothermal, Iceland GeoSurvey Report, ÍSOR-2016/072, 112 p, 1 Map.

[115] Óladóttir, A.A., Óskarsson, F. and Guðjónsdóttir, S.R. (2015) Reykjanes Geothermal Field. Observations on Surface Activity in 2014. Iceland GeoSurvey Report, ÍSOR-2015/015, 45 p.

[116] Guðnason, E.Á. and Ágústsson, K. (2014) Earthquake Swarm on Reykjanes in October 2013. Iceland GeoSurvey Report, ÍSOR-2014/017, 25 p.

[117] Guðnason, E.Á., Ágústsson, K., Gunnarsson, K. and Flóvenz, Ó.G. (2015) Seismic activity on Reykjanes December 2014-December 2015. Iceland GeoSurvey Report, ÍSOR-2015/068, $31 \mathrm{p}$.

[118] Axelsson, G. (2014) Analysis of Tracer Tests Conducted in the Reykjanes Geothermal System 2013-2014. Iceland GeoSurvey Report, ÍSOR-2014/047, 19 p.

[119] Michalczewska, K., Hreinsdóttir, S., Dumont, S. and Sigmundsson, F. (2014) Crustal Deformation on the Western Reykjanes Peninsula 2009 to 2014 Mapped by InSAR and GPS Measurements. Institute of Earth Sciences Report University of Iceland, JH1401, 71 p. 
[120] Khodayar, M., Björnsson, S. and Franzson, H. (2011) Hvammsvirkjun, Holtavirkjun, Urriðafossvirkjun: Synthesis of 2001-2010 Geological Field Data from Hreppar and South Iceland Seismic Zone. Iceland GeoSurvey Report, ÍSOR-2011/032 and Landsvirkjun LV-2011/073, 80 p, 11 Maps.

[121] Jóhannesson, H. (1982) Quaternary Volcanism in West Iceland. In: Fire in the North, Commemorative for Sigurður Pórarinsson, Sögufélagið, Reykjavík, 129-137.

[122] Khodayar, M. (2009) Geological Map of Hallarmúli Volcano, West Iceland, Scale 1:20.000: Bedrock, Tectonics, and Unstable Plate Boundaries. Iceland GeoSurvey Report, ÍSOR-2009/060, 23 p., 1 Map.

[123] Nakamura, K. (1970) En Échelon Features of Icelandic Ground Fissures. Acta Naturalia Islandica, 2, 3-15.

[124] Bergerat, F., Angelier, J. and Villemin, T. (1990) Fault Systems and Stress Patterns on Emerged Oceanic Ridges: A Case Study in Iceland. Tectonophysics, 179, 183-197. https://doi.org/10.1016/0040-1951(90)90290-O

[125] Ágústsson, K. and Guðnason, E.Á. (2014) Fault Plane Solutions for Selected Earthquakes in the Vicinity of the Reykjanes Geothermal Field. Iceland GeoSurvey Report, ÍSOR-2014/043, 26 p.

[126] Keiding M., Lund, B. and Árnadóttir, T. (2009) Earthquakes, Stress, and Strain along an Obliquely Divergent Plate Boundary: Reykjanes Peninsula, Southwest Iceland. Journal of Geophysical Research, 114, B09306. https://doi.org/10.1029/2008JB006253

[127] Khodayar, M. and Franzson, H. (2007) Fracture Pattern of Thjórsárdalur Central Volcano with Respect to Rift-Jump and a Migrating Transform Zone in South Iceland. Journal of Structural Geology, 29, 898-912. https://doi.org/10.1016/j.jsg.2006.11.007

[128] Khodayar, M. (2018) Shift of a Rift by a Transform Zone: Case from Northern Rift Zone and Tjörnes Fracture Zone of Iceland. Petroleum Geoscience. (In Press)

[129] Young, K.D., Jancin, M., Voight, B. and Orkan, N.I. (1985) Transform Deformation of Tertiary Rocks along the Tjörnes Fracture Zone, North Central Iceland. Journal of Geophysical Research, 90, 9986-10010. https://doi.org/10.1029/JB090iB12p09986

[130] Hey, R., Martinez, F., Höskuldsson, Á., Eason, D.E., Sleeper, J., Thordarson, S., Benediktsdóttir, Á. and Merkuryev, S. (2016) Multibeam Investigation of the Active North Atlantic Plate Boundary Reorganization Tip. Earth and Planetary Science Letters, 435, 115-123. https://doi.org/10.1016/j.epsl.2015.12.019

[131] Höskuldsson, Á., Kjartansson, E. and Hey, R. (2004) Seabed Research on the Reykjanes Ridge. Proceedings of the 2004 Spring Conference, Icelandic Geological Society (JFÍ), 10-12.

[132] Friðriksson, P., Sæmundsson, K., Óladóttir, A.A., Einarsson, G.M., Kristinsson, S.G., Ármannsson, H. and Eyjólfsdóttir, E. (2010) Environmental Monitoring of the Reykjanes Geothermal Area (in Iceland). Iceland GeoSurvey Report, ÍSOR-2010/100, $78 \mathrm{p}$.

[133] Óladóttir, A.A. (2012) Application of Soil Measurements and Remote Sensing for Monitoring Changes in Geothermal Surface Activity in the Reykjanes Field, Iceland. Master Thesis, University of Iceland, 110 p.

[134] Tryggvason, E. (1968) Measurement of Surface Deformation in Iceland by Precision Leveling. Journal of Geophysical Research, 73, 7039-7050. https://doi.org/10.1029/JB073i022p07039

[135] Tryggvason, E. (1970) Surface Deformation and Fault Displacement Associated with 
an Earthquake Swarm in Iceland. Journal of Geophysical Research, 75, 4407-4422. https://doi.org/10.1029/JB075i023p04407

[136] Jónsson, J. (1968) Changes at Surface of the Reykjanes Geothermal Area in 1967. National Energy Authority of Iceland Report, 1a/68, 5 p. (In Icelandic)

[137] Ward, P.L., Pálmason, G. and Drake, Ch. (1969) Microearthquake Survey and the Mid-Atlantic Ridge in Iceland. Journal of Geophysical Research, 74, 665-684. https://doi.org/10.1029/JB074i002p00665

[138] Khodayar, M. and Einarsson, P. (2004) Reverse-Slip Structures at Oceanic Diverging Plate Boundaries and Their Kinematic Origin: Data from Tertiary Crust of West and South Iceland. Journal of Structural Geology, 26, 1945-1960. https://doi.org/10.1016/j.jsg.2004.06.001

[139] Kristjánsdóttir, S. (2013) Microseismicity in Krýsuvík Geothermal Field, SW Iceland, from May to October 2009. Master Thesis, University of Iceland, 50 p.

[140] Karlsdóttir, R. (2005) TEM Resistivity Survey in Reykjanes 2004. Iceland GeoSurvey Report, ÍSOR-2005/002, 23 p.

[141] Hickson, C.J. and Níelsson, S. (2015) Tracer Test Reykjanes. Progress Report \#2 January 30, 2015, HS Orka hf., 16 p.

[142] Magnússon, I.P. (2015) GNSS and Gravity Monitoring on the Outer Reykjanes Peninsula in 2014. Iceland GeoSurvey Report, ÍSOR-2015/053, 82 p. (In Icelandic)

[143] Franzson, H. (2000) Reykjanes High-Temperature System. A Study of Fluid Inclusions in Wells RN-9 and RN-10. National Energy Authority of Iceland Report, OS-2000/021, 20 p. (In Icelandic)

[144] Franzson, H., Thórdarson, S., Björnsson, G., Guðlaugsson, S.P., Richter, B., Friðleifsson, G.Ó. and Pórhallsson, S. (2002) Reykjanes High-Temperature Field, SW-Iceland. Geology and Hydrothermal Alteration of Well RN-10. Proceedings of the $27^{\text {th }}$ Workshop on Geothermal Reservoir Engineering, Stanford University, California, 28-30 January 2002, SGP-TR-171.

[145] Tómasson, J. and Kristmannsdóttir, H. (1972) High Temperature Alteration Minerals and Thermal Brine, Reykjanes, Iceland. Contributions to Mineralogy and Petrology, 36, 123-134. https://doi.org/10.1007/BF00371183

[146] Arnórsson, S. (1995) Geothermal Systems in Iceland: Structure and Conceptual Models-I. High Temperature Areas. Geothermics, 24, 561-602.

https://doi.org/10.1016/0375-6505(95)00025-9

[147] Óskarsson, F., Friðriksson, P. and Porbjörnsson, D. (2015) Geochemical Monitoring of the Reykjanes Geothermal Reservoir 2003 to 2013. Proceedings World Geothermal Congress, Melbourne, Australia, 19-25 April 2015, 9 p.

[148] Kadko, D., Grönvold, K. and Butterfield, D. (2007) Application of Radium Isotopes to Determine Crustal Residence Times of Hydrothermal Fluids from Two Sites on the Reykjanes Peninsula, Iceland. Geochimica et Cosmochimica Acta, 71, 6019-6029. https://doi.org/10.1016/j.gca.2007.09.018

[149] Pope, E.C., Bird, D.K., Arnórsson, S., Friðriksson, P., Elders, W.E. and Friðleifsson, G.Ó. (2009) Isotopic Constraints on Ice Age Fluids in Active Geothermal Systems: Reykjanes, Iceland. Geochimica et Cosmochimica Acta, 73, 4468-4488. https://doi.org/10.1016/j.gca.2009.03.033

[150] Berthet, J.C. and Arnaldsson, A. (2015) Comments Regarding the Draft Conceptual Model of the Reykjanes Geothermal Reservoir. Reykjavik, Iceland. Vatnaskil Report, 2015.14.21. 